\title{
質問応答に基づく対災害情報分析システム
}

\author{
後藤 淳 ${ }^{\dagger} \cdot$ 大竹 清敬 $^{\dagger} \cdot$ Stijn De Saeger ${ }^{\dagger}$ 橋本 力 $^{\dagger} \cdot$ \\ Julien Kloetzer ${ }^{\dagger} \cdot$ 川田 拓也 ・鳥澤健太郎 $^{\dagger}$
}

本論文では，地震や津波などの災害時に個人からソーシャルメディア上に発信され る大量の書き込みから，救援者や被災者が欲している情報を自動的に取得する情報 分析システムについて報告する。このシステムでは，質問応答技術により，災害時 の被災地の状況や救援状況を俯瞰的に把握し, 被災地からの想定外も含めた情報を 取得することを目的としている。システムで利用している質問応答処理では構文パ ターンの含意に基づき質問文を拡張し，ソーシャルメディアへの書き込みに対して 地名・場所名を補完することにより，幅広い質問に対応する。さらに，本システム を拡張することにより, 被災地からの重要な情報提供が必ずしも救援者へ届かない 問題に対応できることについて述べる．NPO や自治体などの救援者が状況把握のた めの質問を予め登録しておけば，救援を望む被災者が Twitter や BBS 等へ書き込ん だ時点で，情報を求める側と提供する側の双方に自動的に通知できる。これにより 救援者と被災者の双方向のコミュニケーションが担保され, 救援活動がより効率的 になると期待される。本システムの質問応答性能を我々が用意した 300 問のテスト セットのうち回答が対象デー夕に含まれる 192 問を用いて評価したところ 1 質問あ たり平均 605.8 個の回答が得られ, 再現率は 0.519 , 適合率は 0.608 であった.

キーワード：情報システム，質問応答，災害，ビッグデータ

\section{A Disaster Information Analysis System Based on Question Answering}

\author{
Jun Goto ${ }^{\dagger}$, Kiyonori Ohtake ${ }^{\dagger}$, Stijn De Saeger ${ }^{\dagger}$, Chikara Hashimoto ${ }^{\dagger}$, \\ Julien Kloetzer ${ }^{\dagger}$, Takuya KaWada ${ }^{\dagger}$ and Kentaro Torisawa $^{\dagger}$
}

In this paper we introduce an information analysis system that automatically acquires from social media like Twitter the kind of vital information that rescue workers or disaster victims need in case of large-scale disasters like earthquakes or tsunami. This system uses question-answering (QA) technology with the aim of helping users get a comprehensive overview of the state of affairs and the various conditions of ongoing rescue efforts in the afflicted areas, and detect potentially unanticipated information from the disaster areas. The system expands the input question with various entailment expressions, and augments the original social media input data by analyzing the mentioned place names in order to handle a wide variety of questions relevant to disaster scenarios. Moreover, we extend this system to address rescue workers' crucial problem of getting access to relevant information from the disaster areas in

†情報通信研究機構, National Institute of Information and Communications Technology 
times of crisis. To tackle this problem we introduce a mechanism by which rescue workers from NPOs or municipalities can register certain questions for situation assessment in advance, so that when a disaster victim posts some urgent requests for food, medicines or other essentials on Twitter or some other BBS, both information sender and information requester are automatically notified of this. We expect that such a mechanism can safeguard the two-way communication between rescue workers and disaster victims, and ultimately lead to a more effective rescue effort. We evaluate the system on a test set of 300 questions and their answers. For 192 questions whose answers are actually included in our system's index, we obtained on average 605.8 answers per question, with $51.9 \%$ recall and $60.8 \%$ precision.

Key Words: Information Analysis, Question Answering, Disaster, Big Data

\section{1 はじめに}

2011 年 3 月 11 日に起こった東日本大震災では, テレビ, ラジオなどの既存メディアが伝え きれなかった局所的な情報を，Twitter などの個人が情報発信できるソーシャルメディアが補完 する可能性を改めて知ることとなった。一方で, Twitter 等で発信された大量の情報を効率的に 把握する手段がなかったために, 被災地からの切実な要望や貴重な情報が, 政府, 地方自治体, NPO などの救援団体に必ずしも届かず，救援活動や復興支援が最大限の効率で進展しなかった という可能性も高い. 我々が震災時の Twitterへの書き込み (tweet) を調査したところ, 少なく とも救援者が何らかの対応をしたことを示す tweet が存在しない要請 tweet も非常に多く存在 した。ささらには大量に飛び交うデマを含む情報に振り回された人も多く出た.

こうした状況に対応するため, 自然言語処理を用いて Twitter 上の安否情報を整理することを 目指した「ANPI_NLP」の取り組みが行われたが，開発の速度や多数のボランティアを組織化 するには課題があったことが報告されている (Neubig, Matsubayashi, Hagiwara, and Murakami 2011)，実際に災害が発生してから，新たにTwitter 等のソーシャルメデイアに自然言語処理を 適用し，情報を整理する技術を開発するのは非常に困難であろう。我々は，将来起きる災害に 備えて，事前にそうした技術を開発しておくことが極めて重要であると考えている.

また，我々が被災地で行ったヒアリングでは，現地からの要望とその支援とのミスマッチも 明らかになっている。例えば，テレビや新聞などのマスメディアで伝えられた「被災地で防寒 着が不足している」という情報に呼応して, 多くの善意の人から防寒着の上着が大量に現地に 送られたが, 津波被害にあい泥水の中で復旧作業をする必要のあった人々がより切実に求めて いたのは，防寒のズボンであった。別の例では，全国から支援物資として届けられた多くの衣 類はどれも通常サイズのものばかりで，4L サイズなどの大きな衣類が必要な人が一月以上も被 災時の衣類を着続ける必要があった。これらは，大規模災害発生時に生じる被災者の要望の広 範さや事前にそうした要望を予測しておくことの困難を示す事例と言えよう。さらに，本論文 
で提案するシステムで実際に tweet を分析したところ, 被災地で不足しているものとして，「透 析用器具」「向精神薬」「手話通訳」など平時ではなかなか予想が困難な物資が実際に不足して いる物品として tweet されていることも判明している。こうしたいわば想定外の要望を拾い上 げることができなれば，再度要望と支援のミスマッチを招くこととなる．

以上が示唆することは, 次回の大規模災害に備えて, ソーシャルメディア上の大量の情報を 整理し, 上述した想定外の要望も含めて, 必要な情報を必要な人に把握が容易なフォーマット で届ける技術の開発を災害発生以前に行っておくことの重要性である，また，我々が備えるべ き次の災害が，今回の震災と類似している保証はない，以上のような点に鑑みて，我々は想定 外の質問も含め, 多様な質問に対して, ソーシャルメディア上に書き込まれた膨大な情報から 抽出された回答のリストを提示し, 状況の俯瞰的把握を助けることができる質問応答システム が，災害時に有効であると考えている。

ここで言う俯㒈的把握とは，災害時に発生する様々な事象に関して，それらを地理的，時間 的，意味的観点から分類した上でそれらの全体像を把握することを言う。別の言い方をすれば, その事象がどのような地理的，時間的位置において発生しているのか，あるいはそもそもその 事象がどのような事象であるのか, つまりどのような意味を持つ事象であるのか, 等々の観点 でそれら事象を分類し，また，それらを可能な限り網羅的，全体的に眺めわたし，把握するとい うことである。このような俯瞰的把握によって, 救援者サイドは, 例えば, 重大な被害が生じ ているにもかかわらず，炊き出し，救援物資の送付等が行われていないように見える地点を割 り出し, なんらかの齟䶣の確認や, 救援チームの優先的割当を行うことが可能になる。あるい は各地において不足している物資を, 例えば医薬品, 衣類, 食料といった観点で整理して, 救 援物資のロジスティクスを最適化するなどの処置も可能になる。さらに，こうした俯㒈的把握 によって，上で述べたような想定外の事象の発見も可能になり，また，それらへの対処も容易 になろう。逆に言えば，誰かがこうした俯瞰的把握をしていない限り，各種の救援活動は泥縄 にならざるを得ず，また，想定外の事象に対してはシステマティックな対応をすることも困難 となる。

また，被災者自身も現在自分がいる地点の周辺で何がおきているか，あるいは周辺にどのよ うなリソースが存在し，また，存在しないかを全体として把握することにより，現地点にとど まるべきか，それとも思い切って遠くまで避難するかの判断が容易になる，避難に至るほど深 刻な状況でなかったとしても，周辺地域での物資，サービスの提供の様子を全体として把握す ることで，物資，サービスを求めて短期的な探索を行うか否かの決断も容易になろう。我々の 最終的な目標は，多様な質問に回答できるような質問応答システムを開発することによって， 災害時に発生する tweet 等のテキストデータが人手での処理が不可能な量となっても，そこに 現れる多様で大量の事象を意味的観点から分類, 抽出可能にし, さらに回答の地図上への表示 や，回答に時間的な制約をかけることのできるインターフェースも合わせて提供することによ 
り，以上のような俯瞰的把握を容易にすることである.

本論文では，以上のような考察に基づき，質問応答を利用して，災害時に個人から発信される 大量の情報，特に救援者や被災者が欲している情報を tweet から取得し，それらの人々の状況 の俯瞰的把握を助ける対災害情報分析システムを提案する。将来的には本システムを一般公開 し, 被災地の状況や救援状況を俯㒈的に把握し, 被災地からの想定外の要望をも取得し, 効率 的な救援活動につなげることを目指す。本論文では提案したシステムを実際に東日本大震掞時 に発信された tweet に適用した評価実験の結果を示すが, この評価においては以上のような被 災状況の俯瞰的把握を助ける能力を評価するため, 質問応答の再現率に重点をおいた評価を行 う。逆に言えば，いたずらに回答の上位の適合率を追うことはせず，再現率の比較的高いとこ ろでの評価に集中する。また，本システムを拡張することで，被災者と救援者の間でより適切 な双方向のコミュニケーションが実現可能であることも示す。こうした双方向のコミュニケー ションはより適切かつ効率的な救援活動のために極めて重要であると考えている.

本論文で提案するようなシステムは非常に多くのモジュールからなり，その新規性を簡潔に まとめることは難しいが, 本論文においては以下の手法・技術に関して我々の夕スクにおける 評価，検証を行った，特にCについては，新規な技術であると考えている.

A 固有表現認識 (NER) の有効性

B 教師有り学習を用いた回答のランキング

C 含意関係認識における活性・不活性極性 (Hashimoto, Torisawa, De Saeger, Oh, and Kazama 2012) の有用性

ここで，A，Bに関しては本論文における実験の目標ならびに設定では有効性は認められず， 最終的なシステムではこれらの技術を採用しなかった。これらに関して現時点での我々の結論 は以下の通りである，NER はそれ単体では，我々の夕スクでは有効ではなく，その後の処理や そこで用いられる辞書等との整合性がとれて初めて有効になる可能性がある。また，回答のラ ンキングは, 我々の目標, つまり, 少数の回答だけではなく, 想定外も含めた回答を可能な限り 網羅的に高精度で抽出することには少なくとも現状利用可能な量の学習デー夕, 素性等では有 効ではなかった。一方で，含意関係認識において活性・不活性極性を利用した場合，再現率が $50 \%$ 程度のレベルにおいて, 適合率が 7 \% 程度上昇し, 顕著な性能向上が見られたことから, 提案手法にこれを含めている.

本論文の構成は以下の通りである。まず，2 節において本論文で提案する対災害情報分析シ ステムの構成とその中で使われている質問応答技術について述べる．３節では，人手で作成し た質問応答の正解データを用いたシステムの評価について報告する４４節にて上述した双方向 のコミュニケーションの実現も含めて今後の本研究の展望を示す。さらに 5 節にて関連研究を まとめ, 最後に 6 節にて本論文の結論を述べる. 


\section{2 質問応答に基づく対災害情報分析システム}

\section{1 システム構成}

本システムは，「宮城県で孤立しているのはどこですか」，「福島県で何が不足しているか」な ど，自然言語の質問を入力とし，大規模な tweet コーパスからその回答と思われる表現を抽出 し，ユーザに提示する。（なお，現在，システムはTwitter を主たる情報源としているが，揭示 板や一般の Web 文書などにももちろん適用可能である.）図 1 に示すように，システムは tweet から構文パターンを抽出しインデックスを作成する回答インデックス作成モジュールと，回答 検索時に使用する含意パターンデータベースを作成する含意パターン獲得モジュール，作成さ れたインデックスを用いて回答を抽出する質問応答モジュール，ユーザから入力された質問に 対する大量の回答を効果的に提示する入出力モジュールから成る.

各モジュールの動作の概要は次の通りである．回答インデックス作成モジュールでは，まず tweet を文単位で形態素解析, 構文解析し, 地名補完モジュールにて処理された構文解析結果 から, 詳細については後述するパターンや周辺名詞句を抽出し, これを回答インデックスに含 める.

含意パターン獲得モジュールは, 大規模な Web コーパスを形態素解析, 構文解析したデータ から，含意関係にあるパターン（例えば，「Xから Y まで歩く」は「Xから Y まで移動する」を 含意する）を自動的に抽出し，含意パターンデータベースを作成する．

質問応答モジュールは，ユーザから入力された質問をインデックス作成モジュールと同様に 形態素解析, 構文解析を行い, 質問文からパターンや周辺名詞句を取得する. 次に, 質問文に 含まれるパターンを用いて，含意パターンデータベースを参照し，最大で数千個程度の含意パ

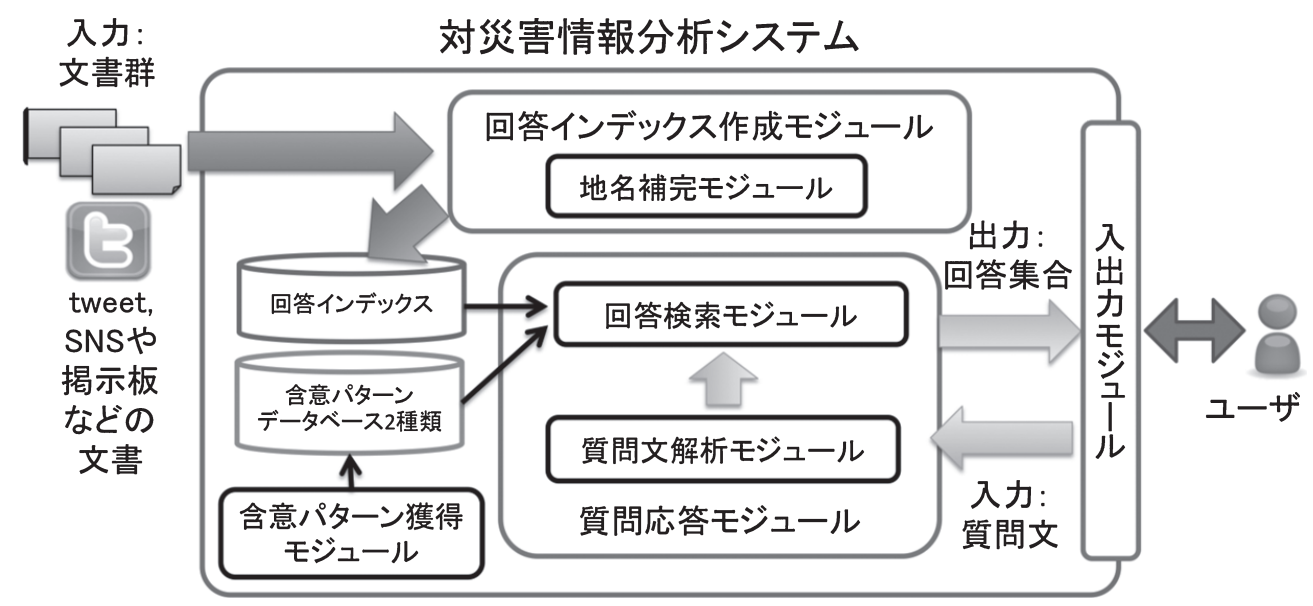

図 1 対災害情報分析システムの概要 
ターンに拡張する。拡張されたパターンや周辺名詞句を用いて回答インデックスを検索し, 回 答を得る.

入出力モジュールは，2 種類ある表示モードの選択, 質問文の入力フォームなどを備え, ユー ザーから入力があるとそれを質問応答モジュールに渡す。質問応答モジュールから回答を受け とると, 表示モードに応じてユーザに回答を表示する.

以下では, これらのモジュールの各々について説明する.

\section{2 回答インデックス作成モジュール}

回答インデックス作成モジュールは, 大規模な tweetのデータを対象に, 高速に質問応答を 行うためのインデックスを作成するモジュールである。回答インデックスの作成には, Apache Jakarta Projectのもとで開発が進められている Lucene ${ }^{1}$ 利用する. 以下ではこのインデック スを回答インデックスと呼び, その役割と作成手順, 作成に際して注意が必要な地名の補完処 理について説明する.

\subsection{1 回答インデックスの作成}

回答インデックスは，ユーザーから入力された質問文から生成したクエリを用いて高速に回 答を取得するためのインデックスである。回答インデックスには，構文情報が充分に存在する 文から抽出される情報を格納する回答インデックス 1 と構文情報が充分にない文から抽出され る情報も格納の対象とする回答インデックス 2 の 2 種類がある.

回答インデックスの作成手順として，まず，対象 (tweet) を文単位で形態素解析，構文解析処 理を行う。形態素解析には $\mathrm{MeCab}^{2}$, 構文解析には日本語係り受け解析器 J.DepP 3 を使用する.

次に，回答インデックス 1 に格納するデータを作成するために構文解析結果における任意の 名詞句 2 つそれらをつなぐ文節係り受けのパスを構成する表層上の連鎖を取得する。例えば, 「宮城県の][炊き出し]」からは，「宮城県」と「炊き出し」という名詞句に係り受けのパスがあ るので「宮城県の炊き出し」が取得される。一方，「[宮城県で][炊き出しが][行われる]」という 結果からは，「宮城県」と「炊き出し」という名詞句の間に「行われる」という文節で媒介され るパスが存在するので「宮城県で炊き出しが行われる」が取得される．このパスを構成する 2 つの名詞句それぞれを変数で置き換えたものを構文パターン，あるいはパターンと呼び，また 構文パターンとそれに含まれる変数に対応する名詞句 2 つの三つ組みをパターントリプルと呼 ぶ. 上記の「宮城県で炊き出しが行われる」という文からは, 構文パターンとして「Xで Yが 行われる」, 変数 X, Y に対応する 2 つの名詞句として「宮城県」と「炊き出し」の三つ組みが

\footnotetext{
1 http://lucene.apache.org/core/

2 http://mecab.googlecode.com/svn/trunk/mecab/doc/index.html 辞書は JUMAN 体系のものを使用.

3 http://www.tkl.iis.u-tokyo.ac.jp/ ynaga/jdepp
} 
この文から抽出されるパターントリプルとなる。またパターントリプルを含む tweet 内の名詞 句を全てを周辺名詞句として取得する。最終的に，回答インデックス 1 には，パターンとして 「XでYが行われる」, 変数に対応する名詞句としてそれぞれ「宮城県」「炊き出し」がキーに登 録され，その值には変数に対応する名詞句と当該 tweet の ID が格納される.

回答インデックス 2 は，回答インデックス 1 に比べて，構文情報が不十分な文も対象とする ために用いる。したがってこのインデックスを用いた回答の信頼性は高くないが，より広範な 回答を得るために使用する。このインデックスでは構文パターンのかわりに部分パターンと呼 ばれるパターンとその周辺名詞句をキーとする，構文パターンは，構文解析結果において二つ の名詞句をつなぐパスから作られたが, 部分パターンは名詞句一つと動詞, 名詞, 形容詞のい ずれかへの係り受け関係から作られる。例えば，「宮城県です。透析用器具が足りません.」と いった tweet からは任意の名詞句 2 つの間に係り受けが存在しないため, 構文パターンを抽出 することはできない. したがって,「透析用器具が足りない」という情報は回答インデックス 1 には反映されない。そこで，構文解析結果において「透析用器具」が助詞「が」を介して「足 りません」へ係っているので，係り元の名詞句を変数として部分パターンを抽出する．この場 合は「X（=透析用器具）が足りません」が抽出され，それと回答インデックス 1 同様に周辺名 詞句である「宮城県」「状況」「透析用器具」とをキーとして, 変数に対応する名詞句, すなわ ち「透析用器具」と tweetの ID とを值として回答インデックス 2 に登録する.

以上 2 種類の回答インデックスのキーと值を表 1 にまとめる. 回答インデックス 1 は上述し たパターントリプルを用いて作成したインデックスであり，回答インデックス 2 は，パターント リプルが取得できない tweetにも対応することで，更に幅広い回答を取得するためのインデッ クスである。 以下に，回答インデックスを用いて，どのように回答を取得するかを説明する.

回答インデックス 1 では, 例えば, 「震災後, 宮城県で透析用器具が不足しています」とい う tweet からは, パターンとして「XでYが不足しています」, 名詞句対（名詞句 1, 名詞句 2) としてそれぞれ「宮城県」「透析用器具」, 周辺名詞句として「震災後」「宮城県」「透析用器具」 「不足」がキーに登録され，その值には変数に対応する名詞句と当該 tweetの ID が格納される. このようなエントリは，例えば「宮城県で何が不足していますか？」といった質問の回答を取 得する際に使われる。この場合，インデックス検索時のクエリは「Xで $\mathrm{Y}$ が不足しています」

表 1 回答インデックス

\begin{tabular}{l|l|l}
\hline インデックス名 & \multicolumn{1}{|c|}{ キー } & \multicolumn{1}{|c}{ 值 } \\
\hline 回答インデックス 1 & $\begin{array}{l}\text { パターン, 名詞句 } 1, \text { 名詞句 } 2, \text { 周 } \\
\text { 辺名詞句 }\end{array}$ & $\begin{array}{l}\text { 回答 } \\
\text { tweetID }\end{array}$ \\
\hline $\begin{array}{l}\text { 回答インデックス } \\
\text { (部分パターン用 })\end{array}$ & パターン, 周辺名詞句 1, 名詞句 2$),$ \\
\hline
\end{tabular}


というパターンと, 「宮城県」という名詞句 1 であり, 検索の結果, 上述した tweetの例から生 成されるインデックスのエントリに值として登録されている名詞句 2 の「透析用器具」が回答 として, tweetのIDとともに出力される。また,「どこで透析器具が不足していますか？」とい う質問であった場合には，「XでYが不足しています」というパターンと「透析用器具」とい う名詞句 2 を持つクエリが生成され, 值に登録されている名詞句 1 の「宮城県」が回答として, tweetの ID とともに出力される。なお，上では周辺名詞句がキーとして登録されると説明した が, Lucene のインデックスのメカニズムでは, キーの一部を省略することが可能であり，例え ば，上の質問の例では，パターントリプルを抽出してきた tweetにあった「震災後」という名 詞句はクエリ中のキーとして現れないが, 適切に検索が行われる.

一方, 回答インデックス 2 のエントリは, 例えば, 「宮城県で何が足りませんか？」という質 問に対する回答を得るためにも使うことができる。質問中では，「宮城県」は「足りません」と いう動詞にかかっているが, この宮城県を周辺名詞句としてとらえ直し（回答が含まれる tweet として「宮城県です。〜が足りません」のようなものもあると想定する)，「何が足りませんか」 という質問中の部分から「Xが足りません」という部分パターンを作成すると回答インデック ス 2 を検索できる。本来であれば, 先の tweetの解析時に照応解析等を行い, 「透析器具が足り ません」という文には「宮城県で」という表現が省略されていることを認識した上で処理を進 めるべきであるが, そもそも照応解析等の精度が高くない現状に鑑み, 照応, 省略表現を一括 して周辺名詞句として扱うことで柔軟な回答の抽出を狙っていることになる.

なお，いずれのインデックスの作成時においても， retweetが入力として与えられた場合には， 同一内容の retweetがあるかをチェックし，もし存在すれば 1 つの retweetのみを登録し，これ と同一内容の複数ある retweet はインデックスには登録しない. 一方ですべての retweet の ID のリストは別途保存しておく，これは retweetの処理によって質問応答の処理時間がのびるの を防ぐための処理である.

\subsection{2 地名補完モジュール}

地名補完モジュールは, 回答インデックスの作成の際に, tweet なとのソーシャルメディアヘ の書き込みで省略されがちな地名や場所名を補完するモジュールである. 地名補完モジュール では大きく分けて次の二つの処理を行う。(1) まず, 構文解析結果をその入力とし, 地名補完の 対象となるエンティティを認識する。(2) 認識されたエンティティの詳細な住所情報を取得し, 元のエンティティの周辺情報に基づいて後述する場所の包含性や, 場所の非明示性の問題に対 処する補完処理を行い構文木に適宜補完要素を挿入する.

災害に関する情報では, 効率的な救援活動などのため, 位置情報や地名が極めて重要である. Twitter では，携帯端末等 GPS 情報を付加できる装置からの書き込みの場合，位置情報の開示 設定がされていれば，その tweetが書き込まれた場所を特定できる．しかしながら，多くのユー 
ザは, プライバシー等の問題から該当機能を有効にはしていない. 災害時の要望等については, この機能を有効とすべきであるが，かならずしもすべての情報に位置情報が記述されている訳 ではない。さらに，通信が不可能なほど壊滅的な被害が発生した場所から，通信が可能な地域 に移動し，当該地域について tweet す場合など， tweetがなされる位置とその tweet が言及し ている位置が, 一致しない場合もある。そのため, tweet内の地名を特定し, 適切に処理するこ とが重要である。しかしながら, 地名の処理には以下のような問題があり, 極めて難しい課題 となっている.

場所の非明示性：Twitter などへの書き込みには, 明示的に県や市の名称が書かれていないこ とが多い.ささらに, tweetに限らず，一般的に，イベントが起きた場所を指す名詞句が イベントを表す動詞等に明示的には係らないことも多く, 動詞で表されたイベントと地 名を結びつけることはそれほど容易ではない.

場所の包含性：場所には包含性がある。例えば，仙台市が宮城県の中にあることを正しく認 識しても，それを処理する手だてがなければ，たとえ文中に「仙台市」と記述されてい ても，「宮城県で」と問う質問には回答できないということが起きる.

場所の曖昧性：一部の地名は非常に大きな曖昧性を持ち, 上記の包含性を扱おうとする場合 に，特に問題となる。例えば，「福島」という地名は日本全国に 50 以上もあり，そこか ら正しい一つを選ぶ必要がある。

地名補完モジュールにて解決したい問題とほぼ同一の問題に取り組んでいるプロジェクトと して GeoNLP ${ }^{4}$ がある。 また, 地名をはじめとする固有表現の認識という点では, 近年 Twitter 等のソーシャルメディアに対する固有表現認識の難しさや, 問題点が広く知られ, 報告も多 くなりつつある (Liu, Wei, Zhang, and Zhou 2013; Ritter, Clark, Mausam, and Etzioni 2011; Cheng, Caverlee, and Lee 2010). Liu らは tweet を対象として K-Nearest Neighbors と Conditional Random Fields を組み合わせた新しい固有表現認識器を提案している. Ritter らは Labled LDA に distant supervision を適用することで高い性能を持つ固有表現認識器を実現している。また, Cheng らは, tweetのみならずWebコーパスを用いた教師なし学習による固有表現認識器を提 案している。

前述した問題に完全に対応することは難しいが, 現在のシステムは以下の手続きによって, 地 名とイベントとを対応付けている，具体的には，まず，現在入手可能なデータから大規模な地 名・場所名辞書を自動生成し, さらに, 地名等の包含性, 曖昧性の一部をヒューリスティック スによって対処しつつ，回答インデックスに地名の情報を取り込んでいる，以下ではこの各々 のステップについて説明する.

\footnotetext{
${ }^{4}$ http://agora.ex.nii.ac.jp/GeoNLP/
} 


\subsection{3 地名・場所名辞書の作成}

地名補完の対象となるエンティティを特定するため, 日本郵便が公開している郵便番号データ と Wikipedia に基づく上位下位関係 (Yamada, Torisawa, Kazama, Kuroda, Murata, De Saeger, Bond, and Sumida 2009) を利用して，地名・場所名辞書を作成した.

まず，日本郵便が公開している郵便番号データを用いて地名辞書を作成した。郵便番号データ からは, 「都道府県/市区町村／町域」で表される住所の情報から，用いられる可能性がある地 名文字列とその詳細な住所との対応を取り出す。地名文字列は「山元」のように断片的なもので ある場合が多いが, こうした対応づけを用いて，断片的な文字列から「宮城県亘理郡山元町」の ようなより詳細な住所が入手可能となる。さらに，「都道府県／市区町村／町域」という住所の 階層性は，先に挙げた場所の包含性に対処するための情報源となる。このようにして, $2,486,545$ のエントリを持つ辞書（地名辞書）を作成した（地名文字列一住所の対の数は $5,129,162$ ). そ のうち，84,633 エントリが曖昧性をもつ地名であった.

また, Twitter などへの書き込みでは, 住所のような地名の他に学校や施設, ランドマーク的 名称の正式名称から通称までが幅広く用いられる。そこで, Wikipedia から抽出した上位下位 関係 (Yamada et al. 2009) から，上位語として自治体をとり，「(自治体名) の (*X)」（Xは「施 設」「学校」など）というパターンにマッチする下位語を取り出して利用した。例えば,「名取 市の増田小学校」などである。これは,「学校」などの, 郵便番号データには載っていないよう な場所にもその詳細な住所を対応づけるためである。上位語中の自治体名を，地名辞書で検索 して下位語に住所を付与する。最終的に，255,273エントリを持つ場所辞書を作成した。

地名辞書と場所辞書をマージすることで, $2,741,818$ エントリを持つ辞書が得られる．地名辞 書も場所辞書もほぼ全自動で作成しているため, それをそのまま文字列マッチによる単純な地 名検出手法とともに適用した場合には，問題となる場合がある．例えば，「枝野官房長官」の名 字と同じ「枝野」が宮城県の地名として使われている場合があるなど，地名には人名と同じもの が多くあり周辺の情報から適切に処理される必要がある。また，高頻出な普通名詞をいずれか の辞書のエントリとして含んでおり，誤って地名処理される場合もある。そこで，このような 問題となるエントリを可能な限りマージした辞書から人手で取り除いた。その結果, $2,726,944$ エントリを持つ地名・場所名辞書が得られた。

地名・場所名辞書は, 地名補完モジュールの性能を決定する極めて重要な知識である. 人工 物に対する固有表現ほど新規エントリや，変更があるとは考えていないが継続的にメンテナン スされる必要がある。このような知識は，ひとたび整備されれば，その多くは長期にわたって 利用可能であるためコストをかけ整備する価值があると考える. 


\subsection{4 地名・場所名特定}

回答インデックスを作成するために形態素解析, 構文解析がされた解析結果の各文節に対し, 形態素をその単位として最長の名詞句を抽出し，地名・場所名辞書を用いて地名・場所名を特 定し, 当該名詞句に詳細な住所候補を付与する。その際, 名詞句全体がマッチしない場合でも, その範囲内で最左のマッチを選び，できるだけ住所を付与する。なお， 1 文字の地名・場所名 は誤ったマッチである可能性が大きいため，無視する.

現在のシステムの地名・場所名の特定方法は, 形態素を単位とする表層文字列が地名・場所 名辞書に存在するか否かによって行うため, 一般名詞等を誤って地名・場所名として扱う場合 がある。そこで，地名・場所名の特定に関して，通常の固有表現認識器を用いることが考えら れる。風間らの報告 (風間, De Saeger, 鳥澤, 後藤, Varga 2012) では, 固有表現認識器の有効性 が確認されておらず, 我々の実験においてもその有効性を確認できなかったため, 現在のシス テムでは, 固有表現認識器を用いていない. 実験の詳細については，3 節にて述べる.

上記の問題以外にも，本システムでは，情報が無ければ最も広範囲な地域を表す住所，直前 に曖昧性解消された住所がある場合には，それと最も整合性のある住所を選ぶルールに基づく 曖昧性の解消を行っている，候補のうち，県・郡・市（郡部の場合は町）部分が tweet 中の文 字列と一致すれば, より広い地域レベルで文字列と一致しているものを優先する。例えば,「福 島」の場合には, 「福島県 : 福島市」「大阪府：大阪市：福島区」等数多くの曖昧性があるが, 最も広範囲な「福島県」が選択される。

\subsection{5 地名補完処理と回答インデックスへの反映}

本システムでは,「イベントの場所は文中で直前に出現した地名・場所である」という仮定を 置き, 元の文の構文解析結果を操作し, 直前の地名・場所 (tweet が複数文の場合は前方の文も 考慮する）に場所を表す助詞「で」を加えたものを，イベントを表す動詞等に係るように付け 加えた新たな構文解析（補完構文解析）結果を生成する.

例えば，「気仙沼中学校へ避難しています」という文があった場合，「避難」イベントの場所 は, 直前の場所である「気仙沼中学校」と認識され, さらに地名・場所辞書により「気仙沼中学 校 $\rightarrow$ 宮城県／気仙沼市」であると分かっているとすると，「宮城県で」，「気仙沼市で」などの 助詞「で」で終わる複数の文節が元の構文木に挿入される。こうしてできた補完構文解析結果 を利用することで, 補完された場所に関連する質問に対応したインデックスが生成される。こ れにより，例えば，元の文には「宮城県」という表現が含まれていないにもかかわらず「宮城 県でどこへ避難していますか」という質問に対し回答（=気仙沼中学校）できる. 


\section{3 含意パターン獲得モジュール}

含意パターン獲得モジュールでは，大規模なコーパスから含意パターンを獲得し，それをデー タベース化する。含意パターンとは，簡単に言うと，あるパターン「Xから Yまで移動する」 を含意する「Xから $\mathrm{Y}$ まで歩く」のようなパターンのことであるが，含意が成立するための名 詞句 $\mathrm{X}, \mathrm{Y}$ にある制約等を考慮するといくつか種類が考えられる。ここでは，クラス依存のパ ターン, クラス非依存のパターンと部分パターンという三種類の構文パターンの含意パターン 獲得及びそのデータベース化について説明する。

\subsection{1 クラス依存のパターン}

クラス依存パターンとは, パターン中の変数に対応する名詞の意味クラスに制約を掛けた構 文パターンである。構文パターンにクラス制約を掛けることでパターンの多義性が解消できる.

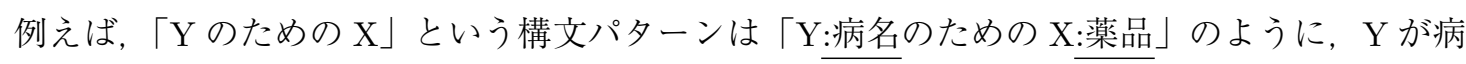
名, $\mathrm{X}$ が薬品の意味クラスの単語の場合は, $\mathrm{X}$ と $\mathrm{Y}$ の治療関係とでも呼べる関係を表し, 上記 のパターン「X:薬品で $\mathrm{Y}$ 病名が治る」の含意パターンとみなせるであろう。一方，「X:作業の ための Y:道具」の場合は手段または道具という意味的関係を表現する。このようにして構文パ ターンと共起する単語を特定の意味クラスに限定することで, 構文パターンの曖昧性が大きく減 らされ，高頻度で曖昧なパターンが活用可能になり，より大量の回答を獲得できる (De Saeger, Torisawa, Kazama, Kuroda, and Murata 2009).

意味クラスは, Kazama ら (Kazama and Torisawa 2008) が提案した単語クラスタリング法に よって自動獲得する。この手法では大規模 Web コーパスから得られる名詞と動詞の係り受け関 係の統計データを用いて, 名詞の隠れクラスへの事後確率の分布を求める. ある名詞の所属確 率が 0.2 以上の隠れクラスを，その名詞の意味クラスとする．現状では名詞 100 万個を 500 ク ラスに分類したクラスタリングデータを用いる.

クラス依存の含意パターンの認識には Kloetzer らが提案したクラス依存パターン間の教師付 きの含意獲得手法 (Kloetzer, De Saeger, Torisawa, Sano, Goto, Hashimoto, and Oh 2012) を用 いる. 詳細については (Kloetzer et al. 2012) を参照されたいが, 含意パターンを認識する SVM 分類器は主に次の 3 種類の手がかりを用いる.

（1）パターンの表層的素性（表層／構造を考慮した素性）。これらの素性は，表層上似ている パターンは含意関係にある可能性が高いという前提で, パターンに含まれる形態素, 内 容語, 構文木の部分木などの bag of words 表現を基に計算した様々な類似尺度から成る.

(2) 分布類似度に基づいた素性. ある構文パターンとその含意パターンの候補に関しては，6 億ページの日本語 Web 文書からパターンの変数に当てはまる名詞句対を検出し，それら の名詞句対の相対的なオーバーラップを計算する，例えば，「Xで $\mathrm{Y}$ を提供」と「Xで $\mathrm{Y}$ を配っている」という 2 つのパターンはX X Y の変数に頻出する共通の単語対（例え 
ば，「石巻市，救援物資」）が多ければ多いほど，これらの構文パターンがお互いの言い 換え表現となっている可能性が高いと考えられる。似た文脈に出現する語は似た意味を もつというのは, 分布仮説 (Harris 1954) と呼ばれる言語学におけるよく知られた仮説で ある。これらの素性はクラス依存のパターンの意味クラスに属する単語対に基づいて計 算した類似尺度から成る。

（3）言語資源に基づいた素性。これらの素性は高度言語融合フォーラムALAGIN で公開さ れた動詞含意関係データベース（ALAGIN リソース A-2），日本語異表記対データベー ス（ALAGIN リソース A-7），基本的意味関係の事例ベース（ALAGIN リソース A-9）と 日本語形態素解析器 JUMAN の辞書から得られた異表記と反対語データを言語資源とし て参照し，両パターンに含まれる内容語が同義語あるいは異表記である場合，または含 意関係や対義関係にある場合など，これらの言語資源に含まれる意味的関係にある時に その情報を素性に加える，更に，Hashimotoらが提案した「活性・不活性テンプレート」 (Hashimoto et al. 2012) も素性として用いる。この活性・不活性テンプレートについては 後述する。

学習データは 51,900 サンプルであり, SVM での学習には 2 次の多項式カーネルを用いた. 図 2 は, 学習データとは異なる 5,338 の評価セットを用いて評価した本分類器から得られるクラス 依存パターン含意の認識精度である。

図 2 から分かるように，上述した条件ではこの手法の上位 1 億対（データサンプル数 49）で は約 $85 \%$ の適合率を示し, 上位 2.37 億にて約 $70 \%$ の適合率を保持している。本論文のシステ

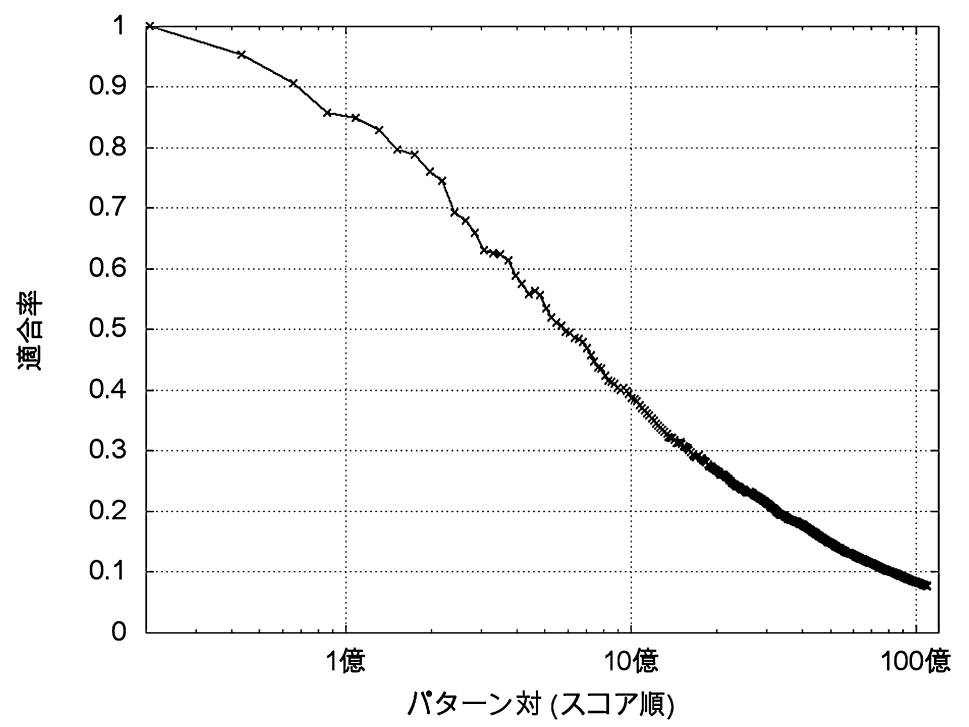

図 2 構文パターン間の含意認識の適合率 
ムで利用される含意パターンデータベースは，後述する方法により質問文から得られる可能性 のある構文パターンの含意パターンを SVM スコアが高いものにしぼって格納しているので, 回 答検索に用いる含意パターンの適合率は図 2 に示される上位の適合率に相当するものと考えら れる。

本システムで利用する含意パターンデータベースを構築するため, まず, (Kloetzer et al. 2012) と同様に, 500 意味クラスの任意のペアのうちで, 同じ名詞句対を異なり数で 3 つ上共有する パターン対すべてを考える。こうしたパターン対の総数は 108 億個存在するが，そのすべてに 対して, 分類器を適用して SVM スコアを求める。 ついで, SVM スコアが計算されたパターン 対の内，以下の手続きで最終的な含意パターンデータベースを構築する。まず，上述のパター ン対に含まれるパターンを「含意されるパターン」Pとして一つ選択し， SVM スコアが 0 以 上のパターンを「含意するパターン」Qとしてスコア上位から順に取得する。「含意するパター ン」Q が500 個を超えた場合は，スコア上位 500 個のみを「含意されるパターン」 $\mathrm{P}$ と対にし てデータベースに格納する。この操作を 108 億個のパターン対に含まれるパターン各々を「含 意されるパターン」P と仮定して繰り返す。なお, 上位 500 個という数值は決定的なものでは なく, システムのパラメータのひとつであるが, 求める性能と応答速度のトレードオフによっ て決まる，現在の 500 という数值は，さまざまな質問をシステムに投入し，経験的に決めたも のである.

\subsection{2 クラス非依存パターン}

クラス依存のパターンでは, 特定の意味クラスの組み合わせにふさわしい含意表現を発見し やすい. 一方，なるべく広い文脈で含意表現として通用するパターンも回答抽出に利用したい. そのために，入力パターンとそのクラス依存の言い換えパターンの集合をクラス非依存の含意 パターン，つまり名詞句に何らの意味的制約が加えられていないパターンで補完する。多くの 意味クラス対で含意パターンとして通用するものは恐らく非常にロバストで一般的な言い換え 表現であるという前提を基に，クラス依存パターン間の各意味クラス対での SVM スコアを平 均したパターン対のデータベースを用意する。あるパターンのクラス非依存の含意パターンは 上記のクラス依存のケースと同様のアルゴリズムで選別する，例外処理として 1 つの意味クラ ス対としか共起しないパターンを除外する.

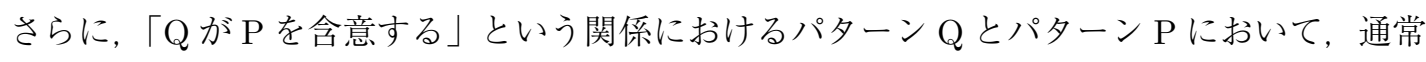
の「Q が $\mathrm{P}$ を含意する」場合のスコアと，逆向きの「 $\mathrm{P}$ が $\mathrm{Q}$ を含意する」場合のスコアが両方 向ともに 0 以上のパターン対のみに限定する。これは確かに片方向の論理的含意関係が成立し ているものの，あまりに意味的にかけ離れているパターン対で回答を認識するのを防ぐためで ある、こうして集められた「含意するパターン」Qは，スコア上位 500 までの「含意されるパ ターン」 $\mathrm{P}$ と共にデータベースに格納される. 得られた $\mathrm{Q} か ゙ 500$ 個未満の場合には, その時点 
までに登録されたすべての $\mathrm{Q}$ と同じ内容語（動詞，名詞または形容詞）を持つ $\mathrm{P}$ をコアの高 いものから順に取得し, データベースに登録する。

\subsection{3 部分パターン}

ソーシャルメディアから得られるテキストはインフォーマルな書き方で知られている。特に Twitterの場合では, tweet が 140 文字以内という制限があるので, 必要最低限の情報しか含ま ない tweet が多い，そのため，二つの名詞句の存在を前提とするクラス依存パターンやクラス非 依存パターンがうまく適用できない場合が非常に多い. この問題に対処するために上記のクラ ス非依存のパターンを一つの名詞句の存在を前提とする部分パターンに分割する。例えば，「X

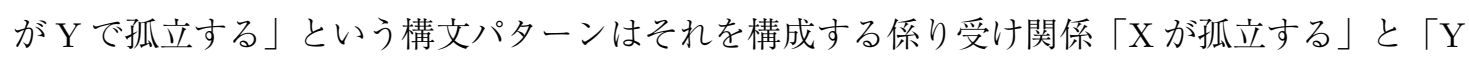
で孤立する」に分割される。

部分パターンの含意パターンデータベースを次のように用意する。既に説明したクラス非依 存パターンの含意データベースを入力とし, それらのパターン対を分割し, 変数毎に部分含意

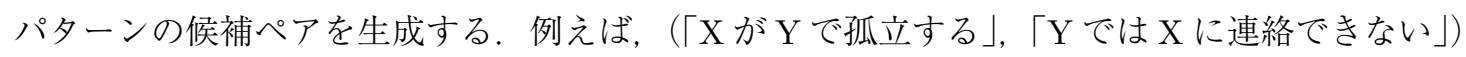
というクラス非依存パターン対から（「Xが孤立する」，「Xに連絡できない」）と（「Yで孤立す る」「Y 「では連絡できない」）という 2 つの部分パターン対を含意候補として生成する。この部 分パターン対の含意スコアはクラス非依存の含意パターンと同様に, その生成元のクラス非依 存の全含意パターン対のスコアの平均とする。ただし，生成元の含意パターン対が 1 ついな い部分含意パターンは一般性に欠けていると考え, 除外する.さらに, クラス非依存パターン と同様に，「Q が $\mathrm{P}$ を含意する」と「 $\mathrm{P}$ が $\mathrm{Q}$ を含意する」の両方向のスコアが 0 以上のパター ン対のみをデータベースに登録する。

\subsection{4 部分パターン対のクリーニング}

以上の方法で作成した部分パターン対は，それがもたらされたクラス非依存パターン対のス コアを平均した值をスコアとして持っているが, パターンに含まれる用言相当表現と変数との 関係を全く考慮していないため，信頼性を欠く場合がある。そこで，次の 2 つの方法で，部分 パターン対をクリーニングする。

・ 活性・不活性極性 (Hashimoto et al. 2012) を用いて部分パターン対を構成する 2 つの゚ ターンの極性が異なる部分パターン対は削除する.

・ 部分パターン対 (P-Q) においてパターンを構成する動詞が $\mathrm{P}$ と Q において同一である が，変数とその動詞を媒介する助詞が異なる部分パターン対は削除する．例えば，「Xが 不足する」と「Xに不足する」などの部分パターン対である。ただし，助詞「は」と「が」 の組み合わせは許容し, 削除しない. 
ここで, 活性・不活性極性とは, Hashimoto らが提案した新しい意味極性であり, 助詞と動詞 の組，すなわち本論文で言うところの部分パターンに対して活性，不活性，中立の 3 つの極性 が付与されている，活性極性が付与された部分パターンはそれを埋める名詞の主たる機能，効 果, 目的, 役割, 影響が準備あるいは活性化することを意味し, その典型例としては「Xを引 き起こす」「Xを使う」「Xを買う」が挙げられる。不活性の部分パターンは逆にそれを埋める 名詞の主たる機能, 効果, 目的, 役割, 影響が抑制あるいは不活性化されることを意味し, 典 型例は「Xを防ぐ」「Xが不足する」「Xを破壊する」などが挙げられる，中立の部分パターン は活性，不活性のいずれも付与できない意味的性質を持つものである.

本研究で含意関係を持つものとして生成された部分パターン対には「Xが不足する」「Xが足 りる」のように意味的には真逆であり，含意が成立していないものが多数含まれた。これは含 意パターン認識で使われている分布類似度がこうした意味的差をとらえられないためであると 考えられる。一方で, 活性・不活性極性に従えば,「Xが不足する」は不活性,「Xが足りる」は 活性であり，それらの差を見ることによって，意味的差異をとらえることができる，我々は，活 性部分パターンを 11,276 個, 不活性部分パターンを 2,764 個, 中立部分パターン 7,523 個を人 手でアノテーションしており，このデータを用いて，部分パターン対で極性が異なるものを削 除した。

以上のクリーニングによって, 当初 $9,192,475$ 個の部分パターン対から $1,819,651$ 個のパター ン対が削除され，最終的に $8,033,759$ 個の部分パターン対がデータベースに格納された。なお， このうち, 活性・不活性極性によるフィルタリングの結果除かれた部分パターン対は $1,158,716$ 個であった。

\section{4 質問応答モジュール}

質問応答モジュールは，ユーザが入力した質問文から回答集合を出力するまでの一連のモ ジュールで構成される。具体的には, 質問文から構文パターンを抽出する質問文解析モジュー ルと，インデックスから回答を検索する回答検索モジュールから構成される。以下に各々の説 明を述べる。

\subsection{1 質問文解析モジュール}

質問文解析モジュールでは，自然言語で入力された質問文の格助詞の変更や疑問代名詞の位 置の入れ替えなどをルールベースで行う。これは, 複数の質問構文パターンを用いてより多く の含意パターンを獲得し，幅広い回答を取得するための処理である。次に，ルールベースで言 い換えられた質問文の構文解析結果から疑問代名詞以外の名詞句一つと疑問代名詞を特定し, その間の係り受け関係パス上にある表現から構文パターンを取得する。例えば，「宮城県で何が 不足していますか」という質問が入力された場合, 「X（=宮城県）で $\mathrm{Y}$ （＝何）が不足してい 
る」という基本的な構文パターンに加え,「YがXで不足している」(格要素の入れ替え),「Y はXで不足している」「Yが $\mathrm{X}$ では不足している」「Xで $\mathrm{Y}$ は不足している」「Xでは $\mathrm{Y}$ が不足 している」(助詞の変換),「Xで不足している Y」(ガ格疑問代名詞の被連体修飾化) などの構 文パターンが得られる。このようにして得られた構文パターンを用いて, 後述する回答検索モ ジュールで回答インデックスを検索するクエリが生成される。例えば,「X（＝宮城県）で $\mathrm{Y}(=$ 何）が不足している」からは，パターンに「Xで $\mathrm{Y}$ が不足している」，Xに対応する名詞句 1 に 「宮城県」を指定したクエリと，部分パターンとして「Yが不足している」，周辺名詞に「宮城 県」を指定したクエリが得られる.

疑問代名詞以外に 2 つ上の名詞句が含まれる場合は, 疑問代名詞と名詞句一つとそれをつ なぐ文節で表される複数のパターンを抽出する。例えば,「宮城県ではどこで携帯が充電できま すか」が入力された場合, 「X（＝宮城県）では $\mathrm{Y}(=$ どこ）で充電できる」，「Y (=どこ)でX (=携帯) が充電できる」の構文パターンが取得される。この結果から, パターンに「Xでは $\mathrm{Y}$ で充電できる」, Xに対応する名詞句 1 に「宮城県」, 周辺名詞句に「携帯」が指定されたクエ リと, パターンに「YでXが充電できる」, 名詞句 1 に「携帯」, 周辺名詞句に「宮城県」が指 定されたクエリが生成される。同時に，部分パターンとして「Yで充電できる」，周辺名詞句に 「宮城県」「携带」が指定されたクエリも生成される。なお，クエリで指定される周辺名詞句は, 質問文に含まれる全名詞句から，パターンや名詞句 1 に含まれる名詞句を除外し作成される.

質問文解析モジュールでは，質問構文パターンの獲得のほか，疑問代名詞に助詞「は」とと もに直接係る名詞がある場合, その名詞を主題語として取得する。例えば, 「被災地で不足して いる食べ物は何ですか」という質問が入力された場合, 名詞「食べ物」を主題語として取得す る.この主題語は, 得られた回答との分布類似度 (Kazama and Torisawa 2008)により，回答候 補を選別するための情報として利用される。例えば，「食べ物」に対して分布類似度が高い上位 の名詞には，「お菓子」，「酒」，「魚」，「肉」，「ワイン」，「チョコレート」などの食べ物が含 まれている。逆に食べ物と関連性の薄い「タオル」や「電化製品」の分布類似度は非常に低い. このように，主題語と回答候補との分布類似度は，質問の回答として相応しくない回答候補を 除外する特徵として利用できる。

\subsection{2 回答検索モジュール}

最終的な回答の取得に際しては, 質問文解析モジュールによって得られた複数の質問構文パ ターンから， 2.3 節で説明した含意パターンデータベースを引くことで質問構文パターンを含意 する含意パターン集合が取得される。ついで，質問構文パターンと質問文中で共起する疑問代 名詞以外の名詞句と含意パターン, 質問文中の周辺名詞句などをキーとして回答インデックス が引かれ，回答と回答が抽出された tweet の ID が得られる.

より具体的に述べると, 一つの質問から得られる複数個の質問構文パターンの各々につき, 
最大で 1,500 個の質問構文パターンの含意パターンが生成される。その内訳はそれぞれデータ ベースに格納されているクラス依存パターンが最大で 500 個, クラス非依存パターンが最大で 500 個, 部分パターンが最大で 500 個となる。これらのパターンは質問文中に出現する名詞句と 組み合わせて回答インデックスの検索に使われる。また，各々の回答インデックスは本論文の 実験では数千万件レベルの大量の tweet をカバーしているため，如何にこの回答インデックス を引く操作を高速化するかが重要になる，現在のシステムでは，Bloom Filter(Bloom 1970) を 利用して，回答インデックスに共起がないパターンと名詞句の組み合わせから成るパターント リプルをメモリー上の操作のみで近似的に検出し，デイスクアクセスを伴う回答インデックス の検索回数を劇的に減らしており，これにより実用的な速度を得ている.

これまでにも述べたとおり，二つの名詞句をつなぐ構文パターンと周辺名詞句をキーとする 回答インデックス 1 は，質問文からパターントリプルが取得できた際に検索される。部分パター ンをキーとする回答インデックス 2 は，二つの名詞句をつなぐ構文パターンが質問文から抽出 されたときも含め, 部分パターンが得られる場合すべてにおいて使用される。ささらに，回答イ ンデックス 2 に対して, パターンやその内容語を周辺名詞句として検索することで, パターン に直接係り受けがない回答も取得できる。また，部分パターンに含まれる内容語のみをとりだ し，それを周辺名詞句として検索することも行う。これは例えば「何が不足しているか？」と いう質問に対して，「不足」のみを周辺名詞句として検索することに相当する.

なお, 抽出された回答にはストップワードフィルター, 場所名フィルター, 非場所名フィル ターが適用される，ストップワードフィルターは，あらかじめ用意したストップワードリストに 回答が含まれる場合にそれを回答リストから削除するものである。ここで使用しているストッ プワードリストは含意パターンデータベース構築の際に用いた 6 億ページの Web 文書から形態 素態素解析器を使って自動的に認識された名詞句（複合語および単語）のうちで，明らかに解 析ミスであり語として認められないものや非常に漠然としており明確な概念を指しているとは 言えないもの（例：「皆さん」「双子以上」「その他」）, さらには主として機能語的に利用される 語（例：「理由」「モノ」）を人手で集めたものである。これは現在 164,064 個の名詞句を含んで いる.

場所名フィルターは, 疑問代名詞「どこ」を含む質問に関して, 前述した地名・場所名辞書に ある語を含む回答, 前述した単語クラスタリングの結果から場所名をさす語を多く含む 48 ク スに含まれる語を含む回答，あらかじめ用意した‘*ホテル’、“*センター’などの場所名のため のパターン 113 個に合致する回答のいずれでもないものを回答リストから削除する。一方で疑 問代名詞「何」を含む質問に関しては，非場所名フィルターを適用する。これは場所名フィル ターを逆に用いて地名フィルターでは削除される回答のみを最終的な回答リストに含めるフィ ルターである。

なお，回答が一文字の場合には，そもそも誤答である可能性が高く，また，後述する再現率 
の計算において問題になるため, そもそも回答リストに含めないこととした.

\section{5 入出力モジュール}

入出力モジュールは，ユーザーから入力される質問を質問文解析モジュールに送信し，回答 検索モジュールから出力される質問に対する複数の回答を提示する。本モジュールはWebブラ ウザーを用いたインターフェースを備えており，一連の操作は Web ブラウザー上で操作でき る。また，回答検索モジュールから出力される大量の回答の俯瞰的な把握を可能にするために， 次に述べる 2 種類のモードで結果を表示する。ひとつは，回答結果を単語の意味クラス毎にま とめて表示するモードであり，もう一方は，場所を尋ねる質問に適した結果の表示方法として， 地図上に回答を表示するモードである。以下で，それぞれについて説明する。

\subsection{1 意味クラスを利用した回答表示モード（意味マップモード）}

意味クラスを利用した回答表示モードでの実行例を図 3 に示す。この回答表示モードでは, 回答が意味クラスごとにまとめられ，異なる色で表示される，色には意味はなく，異なる意味 クラスクラスタであることを示すのみである．意味クラスは (Kazama and Torisawa 2008) で計 算されたものを用いるが，意味クラスの計算対象外であるような長い名詞句に対しては，部分

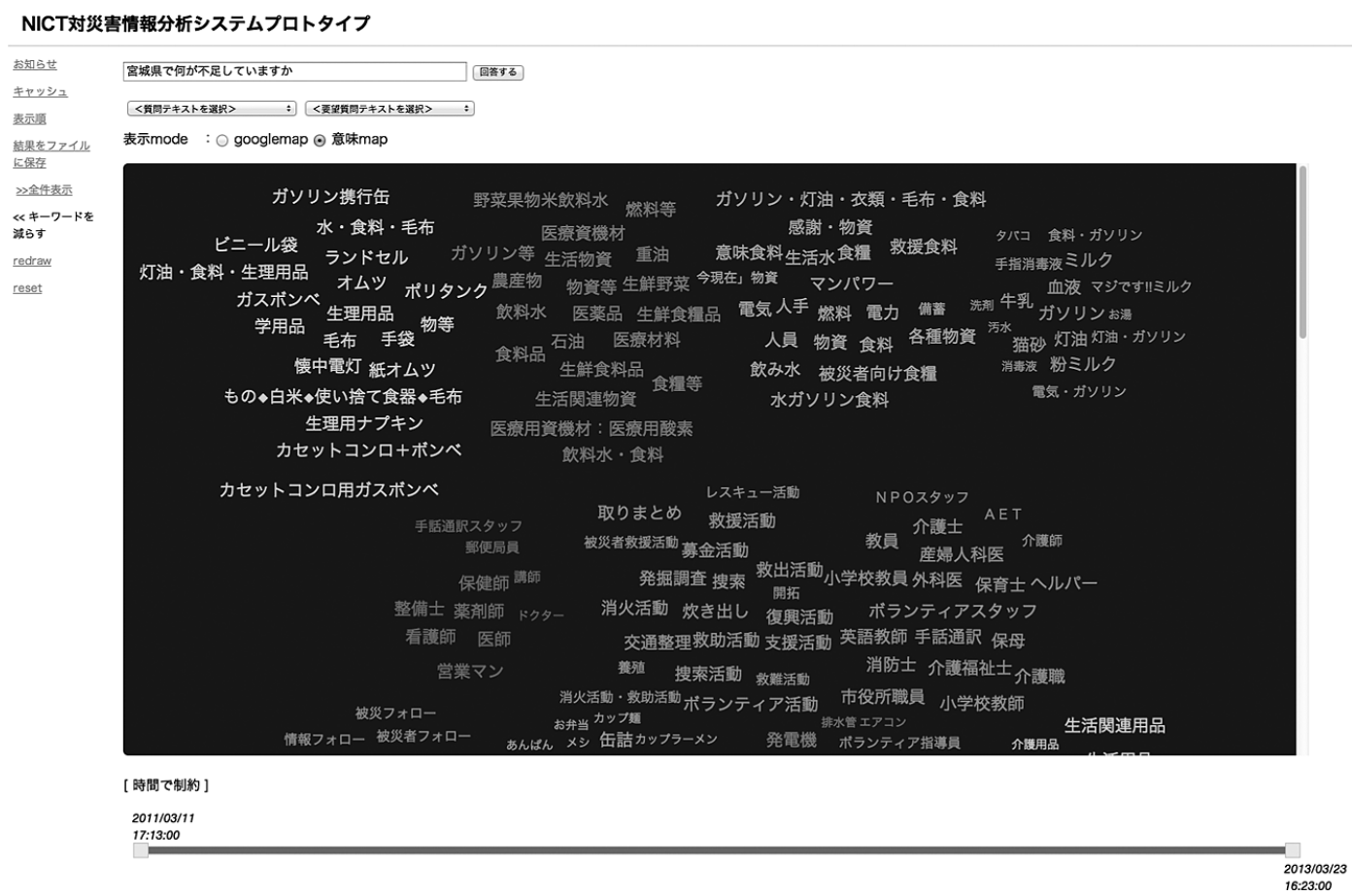

図 3 意味マップモードでの実行例 
マッチを適用するなどして対応する。この表示方法によって，回答を俯瞰的に把握することが 可能となる。回答の文字列をクリックすると, 回答を抽出してきた情報源 (tweet)へのリンク, もしくは回答を抽出してきた tweetそのもの表示するウインドウがポップアップし, 回答が抽 出された tweet の内容を確認できる.

また，画面下部にあるスライダーによって，情報抽出源のテキストの発信時刻による回答の 限定が可能である。回答が抽出されたテキストの発信時刻は，一般の Web ページを対象とする 場合は特定が困難であるが, Twitter や SNS (Social Networking Service) であれば, その情報を 発信した時刻を容易に特定できる。スライダーによって時間帯を指定すると，その時間帯に発 信されたテキストから抽出された回答のみが表示される。特定の期間に発信されたテキストか らの回答が欲しい場合や，古くなった情報を非表示にしたい場合などには，この機能を用いて 必要とする期間に回答をフィルタリングできる.

\subsection{2 地図上へ回答を表示するモード（google マップモード）}

回答を地図上へ表示するモードでの実行例を図 4 に示す。この表示方法では, 質問の回答とな る場所の位置が地図上で表示される，例えば，「宮城県のどこで炊き出しをしていますか」とい う質問に対して，炊き出しが行われている地点が容易に把握できるようになる。この表示モー ドにおいて，質問応答サーバーから受け取る情報は，意味マップモードの場合と同一である． このモードでは，地図上に回答を表示するために，次のことを行う.

（1）質問が場所を尋ねる質問（〜はどこですか，どこで〜できますかなど）の場合，回答は 地名・場所名であることから, 回答に対応する詳細な記述を後述する地名・場所名辞書 から得る。

(2) (1) で得られた記述を使って, geocoding 5 を用いて住所やランドマーク名から緯度経度の 獲得を行い google マップに表示する.

(3) 場所を尋ねる質問以外の場合, 回答の情報抽出源一つ一つに対し, 2.2 .2 節で述べた地名 補完処理で取得した地名の詳細な記述を得る.

(4) (3)で得られた記述を使って geocoding を行い, 地図上に表示する.

地図上に配置されたマーカーをクリックすると, 対応する回答と, その回答が抽出された tweet ヘのリンクが表示される。意味マップモード同様に, google マップモードもスライダーによっ て情報抽出源の発信時刻による回答の限定が可能である.

\footnotetext{
${ }^{5}$ https://developers.google.com/maps/documentation/geocoding/
} 
NICT対災害情報分析システムプロトタイプ

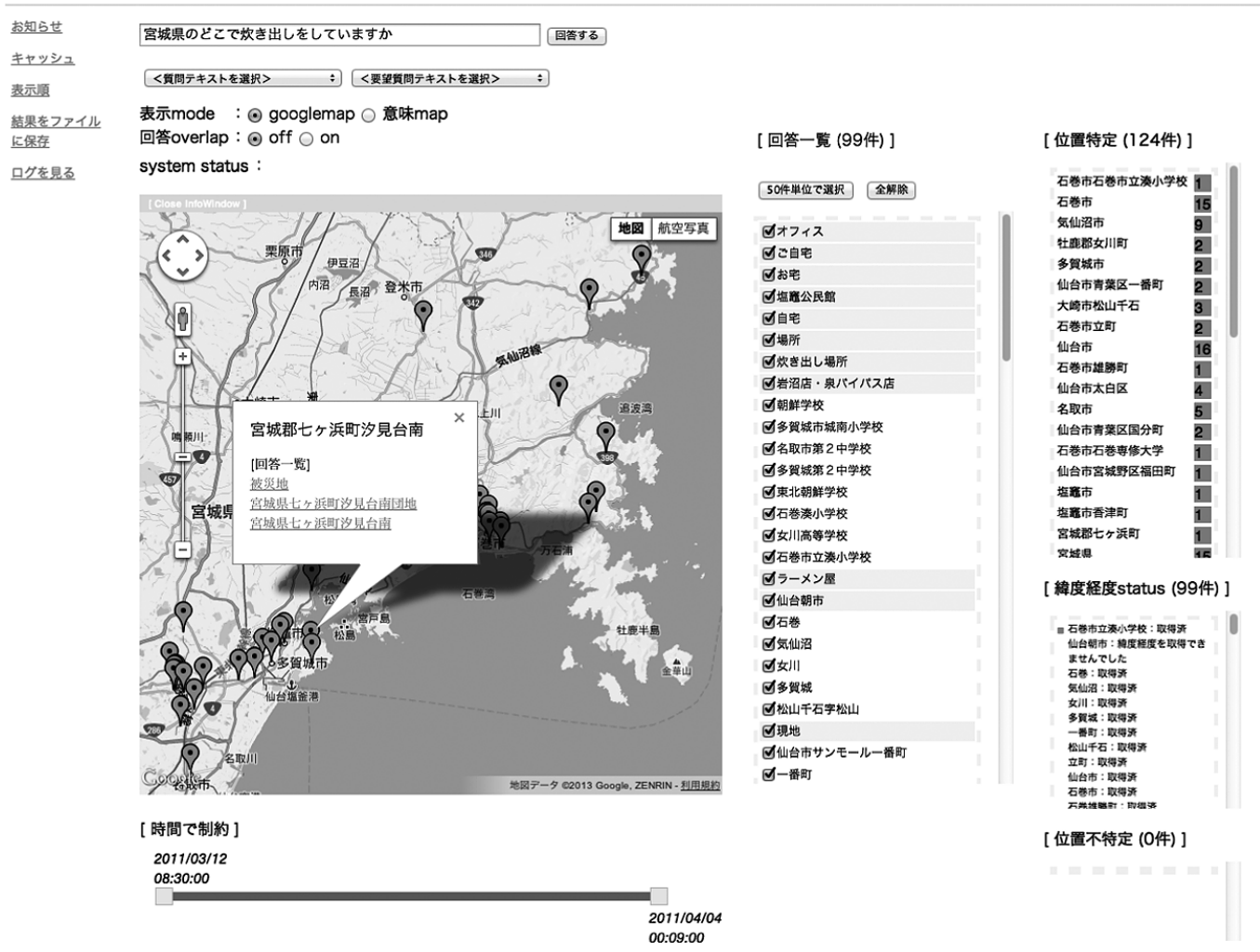

図 4 google マップモードでの実行例

\section{3 システムの評価実験}

本節では，ここまでで述べた方法を実装したシステムを評価する実験について述べる．シス テムが実際に運用される場面を想定したシステムの性能を評価することが望ましいが，本論文 で提案するシステムは非常に多くのモジュールから構成され，その複雑性や，開発途上にある ことを考慮して，システムの基本機能，すなわち質問応答に関して評価を行った。したがって， 本論文での実験では入出力モジュールは，直接的にもシステムに組み込まれた形でも評価され ていない.

システムを評価するために用いたのは，2011 年 3 月 9 日から同年 4 月 4 日までの tweet デー 夕（約 2 億 2 千万 tweet，（株）ホットリンク提供）である。ただし，実験では，災害に関連す る 345 個のキーワードによりフィルターした約 5,400 万の tweet を用いた。この全 tweet から, システムが回答を取得するためのインデックスとして, 約 1 億 2 千万エントリを持つ回答イン デックス 1 と，約 7 億 6 千万エントリの回答インデックス 2 （部分パターン用）が生成された. 
また, 提案システムの評価に加え, 次の項目について実験を行った。 (1) 含意関係認識におけ る活性・不活性極性の有用性を確認する実験. (2) 固有表現認識器 (NER) の有効性を確認する 実験. (3) 教師有り学習を用いた回答のランキングの有効性を確認する実験. このそれぞれに ついても本節で報告する.

\section{1 実験の条件}

災害時における膨大な情報を整理・分析し，全体的な把握を可能とする本システムでは，入 力された質問に対して対象データにおいて目立った回答だけではなく，想定外も含めたロング テール部分に存在する被災者の要望や事実を回答として網羅的に取得する必要がある。そのた め, その再現率が重要な評価指標である.

本システムの性能を評価するためにこれまで我々が大規模に作成してきた評価セットを用い る (川田, 大竹, 後藤, 鳥澤 2013)。この評価セットは, 6 名で予め作成した質問 300 問の各々 について，質問に関連するキーワードでシステムが対象とする tweet 全文検索した結果をラ ンダムに 1,000 件を取得し，その結果から人手で回答を抽出することができた 192 問とその正 しい回答（以下，正答と呼び，その数は 17,524 個である）のセットである. 評価セットの正答 には質問とは表層的に大きく異なる表現で記載された表現から抽出されたものも多数含まれる. 我々が用意した質問は回答が一意に求まるものではなく，ひとつの質問に対して複数の正解が 存在する。また，この評価セットは単に質問と正答，つまり名詞句のペアをデータベース化し ただけではなく，正答が抽出された tweet も含んでいる。実験では，この評価セットを用いた. 再現率は，評価セットに含まれる正答のうちいくつシステムが回答できたかで評価する。当然 ながら，評価セットに含まれていないが，正解と判定される回答をシステムが出力することが 考えられるが，それを考慮して再現率を計算すると，新たな正解が見つかる度に再現率がかわ るため, 評価セットに含まれる正答のみ考慮して再現率を求めた。一方, 適合率は, システム の回答をランダムサンプルし，正解かどうかを人間が判定して求めた．表 2 に実験に利用した 質問の一部を示す.

\section{2 システムの質問応答性能}

評価では, 再現率を計算する際に, システムの回答が正答を部分文字列として含んでいるか, システムの回答が正答に部分文字列として含まれているいずれかの場合を正解とした。その結 果, 再現率 $0.519(9,099 / 17,524)$ が得られた. この部分文字列による照合では, 正答かシステム の回答が一文字である場合に，多数の回答にマッチし，評価の精度が問題になる可能性がある が，前述したように提案システムは一文字からなる単語を回答として出力しない．また，評価 セットの正答で一文字のものは全部で 106 個あったが, システムの出力でそれらにマッチした ものは 67 個であった。 これはシステムの回答の $4 \%$ 程度に相当する。しかし，これらすべてを 
表 2 実験に利用した質問例

\begin{tabular}{|c|c|c|}
\hline カテゴリ & & 例 \\
\hline インフラ & $\begin{array}{l}\text { どこに給水車が来ますか } \\
\text { 停電した時の注意点はなんですか }\end{array}$ & どこでガスが復旧していますか \\
\hline 物資 & $\begin{array}{l}\text { 必要な家電は何ですか } \\
\text { 支援物資の受付空口はどこですか }\end{array}$ & スポーツドリンク代わりになる物は何ですか \\
\hline 生活 & $\begin{array}{l}\text { どこでお風呂に入れますか } \\
\text { 営業しているお店はどこですか }\end{array}$ & どこで遺体の火葬をやってもらえますか \\
\hline ボランティア & $\begin{array}{l}\text { ボランティアに適した服装は何ですか } \\
\text { どこで復旧作業が行われていますか }\end{array}$ & 介護士のボランティアはどこで募集していますか \\
\hline 支援活動 & $\begin{array}{l}\text { どこで募金ができますか } \\
\text { どこで炊き出しをしていますか }\end{array}$ & 支援が必要なのはどこですか \\
\hline 情報・交通 & $\begin{array}{l}\text { どこで携带電話の電波は入りますか } \\
\text { 機能している空港はどこですか }\end{array}$ & どこで道路が寸断していますか \\
\hline 災害状況 & $\begin{array}{l}\text { 津波の高さはどのくらいですか } \\
\text { どこで土砂崩れが起きていますか }\end{array}$ & 震災による経済的損失はいくらですか \\
\hline 病気・負傷 & $\begin{array}{l}\text { はやっている病気は何ですか } \\
\text { 不安解消に効くものは何ですか }\end{array}$ & クラッシュ症候群の注意点はなんですか \\
\hline 原発·污染 & $\begin{array}{l}\text { 放射能が高いのはどこですか } \\
\text { 線量はどのくらいですか }\end{array}$ & なにが污染されていますか \\
\hline 安否確認 & $\begin{array}{l}\text { どこで安否確認ができますか } \\
\text { 救援を求めているのはどこですか }\end{array}$ & どこで身元の確認ができますか \\
\hline 政府·行政 & $\begin{array}{l}\text { どこに自衛隊がいますか } \\
\text { 緊急車両が通れる道はどこですか }\end{array}$ & 自治体の就労支援には何がありますか \\
\hline
\end{tabular}

回答から除外した場合の再現率は， $0.519(=(9,099-67) /(17,524-106))$ と変わらず，この影 響は小さいと考える。また，192の質問ごとに再現率を求め，その平均をとると 0.428 であっ た.これは，もともとの正答数が小さい質問において，再現率が 0 となってしまう場合が多い （192 問中 41 問，そのうち回答数が 0 のもの 32 問）ためであり，このことから，逆に質問の 正解が得られた場合の再現率は，この数值よりも大きい場合が多いことを期待できる.

適合率に関しては, 全回答から質問と回答のペア 250 個をランダムサンプルし 3 名の評価者で 正解かどうかを調べ，その多数決により正解を決めた。評価者間の一致度合は Kappa 值 (Fleiss 1971) が 0.507 であった，回答の評価に際しては，回答が抽出された元の tweet が非常に大量の 場合があるが，ランダムに選択した最大 3 個の tweet から正解かどうかを判断した．評価の結 果, 250 問の適合率は, $0.608(152 / 250)$ となった。

例えば，構文パターンを利用した質問では，「どこで風評被害が起きていますか」という質問 の回答では,「YでX（=風評被害）が出ている」「X（=風評被害）が $\mathrm{Y}$ で発生している」「Y

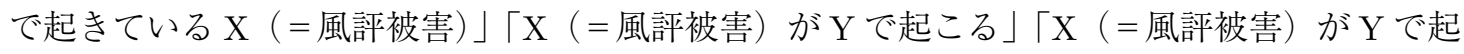
きている」などのパターンにより回答を取得している. 
また，部分パターンを利用した質問では，「なにが污染していますか」という質問で「Yが污 染されてしまう」「Yが污染される」「Yの污染」などのほか，「Y功検出される」「Yからは 検出される」などの部分パターンが含意パターンデータベースから取得され利用された. これ により「4 号機, 正門, ヘリ」などの tweetに「污染」を含んでいない回答も得ることができて いる.

再現率を下げている要因の一つとしては, 回答がまったく取得できない質問が 32 問あること がある。これらの多くは，質問文を構成する名詞句が tweetにおいて非常に低頻度であり，手掛 かりとして役に立たない場合である。例えば，「専門職ボランティア」，「被災者相談空口」，「被 ばく相談」，「被災者就労支援」などの複合名詞や，「津波肺」「クラッシュ症候群」「誤嚥性肺炎」 などの固有名である。これらは，該当する複合名詞や固有名が回答インデックスに存在しない か登録されていても非常に少数であった。対応策としては，「被災者相談空口」を「被災者の相 談空口」とするなどの複合語の分割が有効であり，さらにサ変名詞を語尾にもつ「被ばく相談」 「就学支援」のように複合名詞が「行う」「できる」「実施する」などに係る場合は，「被ばくを相 談する」，「就学を支援する」などのより汎用的な表現に変換することが必要である．今後，複 合語の構造解析手法などを取り入れ，より幅広い質問にも対応できるようにする予定である.

また，適合率を評価した回答 250 についてより詳細に分析した，これらの回答がどういった 処理によって抽出されるかを見るとまず, クラス依存, クラス非依存をふくめて「Xが Y で不 足している」のように二つの変数を含むパターンによって得られた回答は全体の $6 \%$ (15 個) で あり，その適合率は 0.933 であった。 また，「Y が不足している」のような部分パターンで抽出 された回答は $72 \%$ (180 個) を占め, 適合率は 0.656 であった. さらに部分パターンの内容語を 抽出して得られた回答は $22 \%$ （55 個）であり適合率は 0.364 であった。期待されるように制約 の強いパターンで取得されている回答は適合率が高いものの, 変数を二つ含む複雑なパターン の適用例はきわめて少なかった。 これは「どこが渋滞していますか？」のようなそもそも二つ の変数を含むパターンが抽出できない比較的簡単な質問が我々の評価セットに多かったことも 理由である。今後「宮城県のどこで渋滞していますか？」のようなより複雑な質問を評価セッ 卜に加えると, この制約が強いパターンが適用される割合も増加するものと考える.

誤った回答が抽出された要因を見ていくと，もちろん，パターン間の含意の認識誤りも含ま れてはいるが, むしろ目立つのは「水は不足していますか？」「水が不足したりして」「水は不 足していません」などのように単純な肯定文以外の文から「Xが（は）不足する」のようなパ ターンが抽出されている場合である。これらの文をムード等の分析ルーチンを導入することに よって除くことで最大で 10 \%以上の適合率改善ができると予想している。方で，「水は不足 していますか？」のような質問や要望，「水が不足していたとしたら」のような仮定も，災害時 において非常に有用な情報であり，個別に認識することは重要な課題だと考えている。

また，地名補完処理の誤りによって，パターンやその内容語から離れた位置に出現する場所 
名が誤って回答として抽出されるケースがあった。 これらは今後, 省略, 照応解析を導入する ことで改善していく予定である。

\section{3 部分パターン対のクリーニングの効果}

2.3 節で述べた部分パターン間の含意関係のクリーニングが質問応答全体に及ぼす影響につい て評価を行った。部分パターン間の含意関係とは，例えば「Xが崩落する」「Xが崩壊する」の 間に成立する含意関係である，2.3節で述べたように，このクリーニングにおいては，活性・不 活性極性を用いたクリーニング（活性・不活性クリーニング），ならびに同一の動詞を含む部分 パターン間で助詞のみが異なるものを削除するクリーニング（助詞クリーニング）の二種類を 行った。

まず，提案システムの再現率は 0.519 , 適合率は 0.608 であったが，部分パターン間の含意関 係に対して助詞クリーニングのみ適用し，活性・不活性クリーニングを適用しなかった場合の 回答を, 提案システムと同様に回答 250 サンプル（評価者 3 名による評価）を抽出し，評価し たところ, 表 3 に示すとおり，再現率 0.524 , 適合率が 0.536 となった。つまり，再現率は 0.005 とわずかに向上したが, 適合率が 0.072 と大きく低下したことになる. さらに, 活性・不活性ク リーニング, 助詞クリーニングの両方を適用しなかったときの性能は, 再現率が 0.533 , 適合率 が 0.448 となり，やはり再現率がわずかに向上したものの適合率の大幅な低下が見られた．最 終的にいっさいクリーニングを行わなかった場合と提案手法を比べると，再現率が 0.014 程度 向上するのに対して，適合率は 0.160 と大幅に低下している。まとめると，部分パターン対の クリーニングは最終的な回答の質において非常に重要であるということが分かった。特に，一 見含意関係とは関係の薄い, 活性・不活性という意味極性がそのクリーニングにおいて重要な 役割を果たすことが確認できた。

\section{4 固有表現認識器の効果}

本研究での提案システムは地名補完モジュールにNER を使用しなかったが，それは以下の 実験結果により，NERの有用性が本システムにおいて認められなかったからである。

まず, IREX 固有表現コーパス (Sekine and Isahara 2000)において LOCATION タグのみを残 し, これを NER 学習データ 1 とした. 次に, Twitter API を使用して, 実験で用いる tweet と

表 3 部分パターン対のクリーニングの効果

\begin{tabular}{l|c|c}
\hline & 再現率 & 適合率 \\
\hline 提案システム & 0.519 & 0.608 \\
活性・不活性クリーニング未使用 & 0.524 & 0.536 \\
活性・不活性及び助詞クリーニング未使用 & 0.533 & 0.448 \\
\hline
\end{tabular}


は異なる期間の tweet 22 万 5 千件を取得し，これに対し，災害関連のキーワード 345 個のいず れかを含む 11 万 tweetに対して学習データ 1 から作成した既存の NER を適用し, LOCATION タグを付与した。 この結果のうち 4 万文を人手で修正し, これを NER 学習データ 2 とした。こ れらの NER 学習データ 1 ならびに 2 をあわせて NER 構成用学習データとし, CRF++ ${ }^{6}$ を用い て形態素単位の NER を構成した，素性テンプレートは CRF++パッケージのサンプルとして含 まれているものをそのまま利用した。

この NER を評価するために, 我々が対象としている 5,400万の tweet から 1,000 tweet（3,017 文）をランダムサンプルし，構成した NER を適用した。 その結果を人手で修正し，評価用テス トセットを作成した，この評価用テストセットの形態素数は約 33,000であり, LOCATION と される名詞句は，521 (866 形態素) 存在する。これを用いて構成したNER を評価したところ 適合率は 0.930 , 再現率は 0.839 であった.

次に我々の質問応答システムで，地名補完モジュールにおける処理対象の特定にNERを組み 入れた場合と，形態素単位の文字列によって直接辞書引きすることで特定する場合との違いが システム全体の質問応答性能に与える影響を調べた。実験に使用したのは, 部分パターン対の クリーニングを行う前のシステムであるが, NERの効果を調べるには問題がないと考える．表 4 に示すとおり，実験結果は，NER を用いない場合が再現率 0.533 , 適合率 0.448 であり, NER を用いた場合には再現率 0.516 , 適合率 0.392 と再現率, 適合率ともに低下した。この結果から, あるエンティティが地名・場所名辞書に存在しているにもかかわらず，NERがそれを特定でき なかった場合や，逆にNER が地名補完モジュールでの処理対象を特定できても地名・場所名辞 書に登録されていない場合などがあり，地名・場所名辞書を直接辞書引きしたほうが，より高 い性能を発揮できたと考える.

より具体的に，NERで特定されたものがどれだけ地名・場所名辞書を用いて地名補完処理さ れたかを見てみると次のようになった。 NER はテストセットに 521 あるエンティティのうち, 437 (再現率 0.839) 相当を正しく特定できているが, このうち, 地名補完処理の対象となった のは, わずか 157 個である。この数字が小さい理由は, 現在の地名補完処理はシステムの持つ 地名・場所名辞書にあるエントリしか処理対象としないからであり,さらには NERの認識結果 と地名・場所名辞書との食い違いが大きいからである. 一方, 地名補完モジュールにて行って

表 4 固有表現認識器 (NER) の効果

\begin{tabular}{l|c|c}
\hline & 再現率 & 適合率 \\
\hline 固有表現認識 (NER) 未使用 & 0.533 & 0.448 \\
固有表現認識 (NER) 使用 & 0.516 & 0.392 \\
\hline
\end{tabular}

${ }^{6}$ http://crfpp.googlecode.com/svn/trunk/doc/index.html 
いる処理では, 214 個の地名・場所名を特定し, 地名補完処理がなされた。もちろん, この地名 補完処理がなされた地名・場所名には誤ったものも多数含まれていよう。もともと NER を導 入した動機は，NERによって一般名詞や人名等を地名として誤認識することを防げるかもしれ ないということであった。つまり, 地名補完処理対象認識の適合率の向上をねらったというこ とである，おそらく，地名・場所名の誤認識がNERによって防がれたケースもあったものと推 測されるが，そもそも地名補完処理が起動されないことのデメリットの方が大きく，最終的な 質問回答の性能が低下したものと考える。

もちろん, 今後 NERの認識結果を地名・場所名辞書に追加していくことによって, 性能向 上を見ることは可能かもしれない. しかしながら，そこで障害となるのはエンティティの基準 と, 地名補完処理において処理対象とするエンティティ, すなわち地名・場所名辞書のエント リの認定基準とが異なっていることである，例えば，NERの認識結果には外国の地名などあき らかに本タスクでは不要と思われるものも多数存在するし, 複合名詞中, 例えば「富士スピー ドウェイ」の「富士」が地名として認識されるといった問題も存在する。また，地名・場所名 辞書では地名間の包含関係が情報として含まれているが，NERの認識結果にはそうしたものは 含まれない.これらの問題をどう解決していくかが, 今後の課題の一つとなる.

まとめると，風間ら (風間 他 2012)の報告と同様に提案システムにおける NER の効果は確認 出来なかった。これをうけて, 我々の提案システムではNER を使用していない. この理由は, 現状の地名補完処理では, 固有表現特定後に地名・場所名辞書にて詳細な地名情報を取得する 必要があり，この辞書の網羅性等が性能に影響するためである。さらには，地元でだけ用いら れる通称など考慮しなければならない点もあり, これらの問題点をいかに低コストで解決して いくかも重要な点であると考えている，今後，自治体などの協力を得て，そうした通称や未登 録の避難所をリストアップしていくなどの作業も必要であろう。したがって，システムの性能 を向上させるためには，NERの認定基準と本夕スクで必要とされる地名・場所名の認定基準と の擦り合わせ，さらには地名・場所名辞書との整合性をとる自明でない作業が必要となる.

\section{5 回答のランキング}

本論文におけるシステムでは，ロングテールに存在する回答についてもすべて出力するとい う目的から，再現率を重視し，今まで述べてきた手法で発見できたすべての回答を出力してい る。一方で, 自明な拡張は回答にランキングメカニズムを導入し, さらなる拡張を図ることで ある，本来，再現率を重視しつつ，ランキングを導入し，提案手法よりも高い性能を達成する ためには，提案手法よりも公汎な回答を出力し，ランキングに基づいて回答の足切りを行うべ きであるが，現状はそこまでの実験は行えていない，代わりに，提案システムが出力する回答 全部を教師あり学習に基づいてランキングした結果について報告する.

今回行った実験で使ったランキング手法は，回答とパターンに関する素性をもとに学習した 
SVM のスコアによりランキングを行うものである. 表 5 に, SVM の学習に利用した素性を示す. まず，パターンの属性に基づく素性として，質問構文パターン，クラス依存パターン，クラ ス非依存パターン，部分パターンからのいずれのパターンで回答が得られたか，あるいは部分 パターンと部分パターンの内容語によるキーワード検索を用いたかを示す 2 值の素性を用いる. これに加え, クラス依存パターン, クラス非依存パターン, 部分パターンの各スコアを用いる. ある回答が複数の異なるパターンから得られた場合には，その全パターン数，パターンが回答 を連体修飾していないどうか, 全パターン数と回答を連体修飾していないパターンとの比率を 利用する。また回答を抽出した含意パターンや部分パターンが, 質問構文パターンと共通の漢 字を持つかどうかも利用する.

回答の属性に基づく素性では，まず，様々なパターンから得られた同じ回答の個数，その文

表 5 回答のランキングに使用する素性一覧

\begin{tabular}{|c|c|}
\hline 素性の種類 & 内容 \\
\hline パターン & 質問構文パターンにより回答が得られたかどうか \\
\hline パターン & クラス非依存パターンにより回答が得られたかどうか \\
\hline パターン & クラス依存パターンにより回答が得られたかどうか \\
\hline パターン & 部分パターンにより回答が得られたかどうか \\
\hline パターン & 部分パターンでのキーワード検索により回答が得られたかどうか \\
\hline パターン & 部分パターンの内容語でのキーワード検索により回答が得られたかどうか \\
\hline パターン & クラス依存パターンのスコア \\
\hline パターン & クラス非依存パターンのスコア \\
\hline パターン & 部分パターンのスコア \\
\hline パターン & 回答を取得したパターン数 \\
\hline パターン & 連体修飾型でないパターンの有無 \\
\hline パターン & 回答取得したパターン数と連体修飾型でないパターンとの比率 \\
\hline パターン & 質問構文パターンと同じ漢字を含むパターンの有無 \\
\hline 回答 & 複数のパターンから得られた同じ回答の個数 \\
\hline 回答 & 回答の形態素数 \\
\hline 回答 & 回答の文字数 \\
\hline 回答 & 回答の意味クラス \\
\hline 回答 & 未特定の意味クラスかどうか \\
\hline 回答 & 部分文字列によるクラス特定を利用したかどうか \\
\hline 回答 & 構文パターンと 2 つの名詞句の意味クラスの PMI \\
\hline 回答 & 質問構文パターンと質問文中の名詞に基づく回答の意味クラスの尤度 \\
\hline 回答 & 疑問代名詞タイプ \\
\hline 回答 & 回答が疑問代名詞の対応するクラスに属するかどうか \\
\hline 回答 & 回答と主題語との分布類似度 \\
\hline 回答 & 回答が主題語の下位概念かどうか \\
\hline 回答 & 回答の末尾が主題語となるかどうか \\
\hline
\end{tabular}


字数及び形態素数を用いる，次に，回答の意味的な情報として，回答の意味クラス，その意味 クラスを特定する際に部分文字列を用いたか, 回答のクラスが未特定かどうかの 2 值の素性を 用いる。また，回答を獲得したパターントリプルの構文パターンと 2 つの名詞句の意味クラス の PMI（相互情報量：Point-wise Mutual Information），質問構文パターンと質問文中の名詞に 基づく回答の意味クラスの尤度 (De Saeger et al. 2009) を利用する。また質問文から得られる疑 問代名詞と主題語を利用した素性として，疑問代名詞タイプ，回答が疑問代名詞の対応するク ラスに属するかどうか, 回答と主題語との分布類似度, 回答が主題語の下位概念となるかどう か, 回答の末尾に主題語を含むかどうかを用いる。

上記の素性を用いて, 線形, 多項式 (二次), 放射基底関数 (RBF, 比例定数 1）の各カーネル を用いて SVM の学習を行い，いずれのカーネル関数を用いるべきか検討した。学習データは, 災害に関連の深い質問 60 問（これまでの評価で利用した質問とは別である）と，システムが出 力した回答のペア合計 5,044 個に対して正解/不正解のラベルを付与したデータである. なお, このデータは提案システムの古いバージョン，つまり，場所名フィルターや部分パターン含意 データベースのクリーニングを行っていないシステムの出力を含んでおり, 現在の提案システ ムでは出力できない回答も含まれている。10 分割交叉検定の結果, 線形カーネルで $\mathrm{F}$ 值 0.642 (適合率 0.681 , 再現率 0.607), 多項式カーネルで $\mathrm{F}$ 值 0.631 （適合率 0.626 , 再現率 0.634 ), $\mathrm{RBF}$ カーネルで $\mathrm{F}$ 值 0.529 （適合率 0.719 , 再現率 0.419 ）が得られた。本システムでは $\mathrm{F}$ 值が最も 高かった線形カーネルにより学習された分類器の出力するスコアを利用することを検討した.

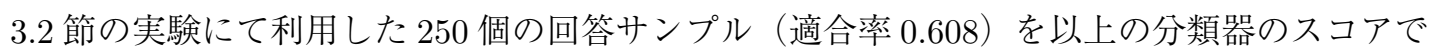
ランキングした結果が図 5 である。グラフの再現率は提案システムの出力すべてを SVMのスコ アにしきい值をもうけて足切りを行い, 足切りを生き延びた回答集合を 17,254 件の正解デー夕

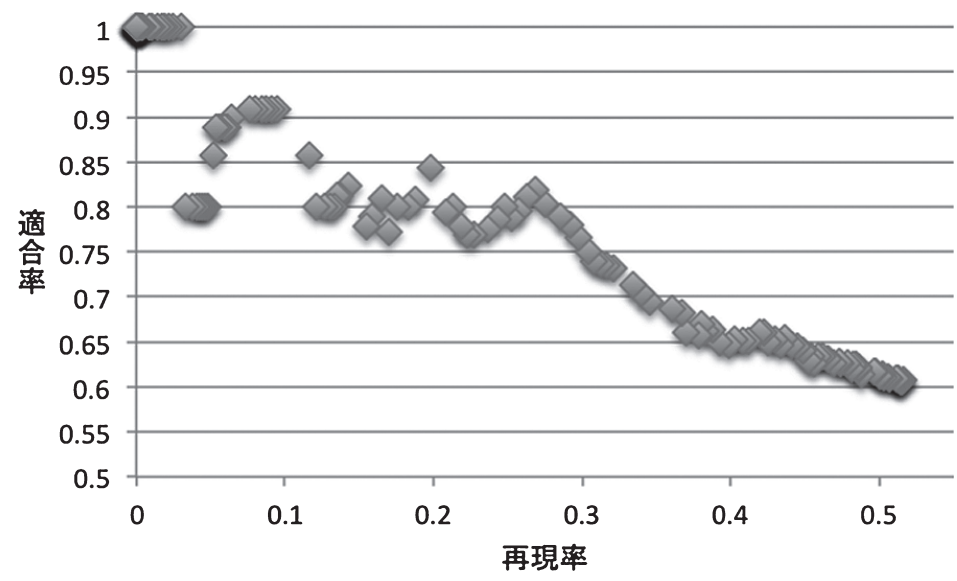

図 5 回答のランキング結果 
に照らし合わせて計算されたものである。これによると, 再現率が 0.1 前後のところでは適合 率が 0.90 前後でており, きわめて高いものとなっている一方, システムの全回答の再現率 0.508 に近いところ, 例えば, 再現率 0.4 前後のところでは提案手法の適合率に比して, わずかな適 合率の向上（0.05 前後）しか見られず，また，もうすこし離れたデータポイント（例えば，再 現率 0.3 前後のデータポイント）までの適合率の改善具合もきわめてなだらかである.

この評価はあくまで現状のシステムの出力結果のみをランキングしているため, 確定的なこ とは言えないが, 前述したように学習データは現在のシステムが出力できない回答に関するも のも含まれていないことも考え合わせると，仮に現在のシステムをより大量の回答を出力する ように改変し，ランキングによる足切りをおこなったとしても，例えば, 再現率 0.5 前後の部 分での適合率向上はきわめて小さなものになる可能性が高いと考えられる。これは再現率を重 視するという我々の立場とは相容れないものであり，提案システムにはランキング手法は導入 しなかった。

一つ今後システムを改善できる可能性があるとすれば，今後さらに学習デー夕を増やしてい くことが重要であるが, 現在でも約 5,000 件という少なくない量の学習データを利用しているこ と，また，次回の災害は抏そらく東日本大震災とは大きく異なることが予想され，東日本大震災 に特化した学習データを作ることは望ましくないと考えられることから, 少なくともランキン グ手法の導入については慎重に検討する必要があると考えている，実際に大規模な災害が発生 した後,アノテーションをクラウドソーシングなどで行い, 質問応答の精度を高めるといったシ ナリオは魅力的に見えるかもしれない。しかし，そうしたシナリオを実現するためには，NER の場合と同様にシステム全体としての最適化の枠組みなどが必要だということかもしれず，こ れも慎重に検討する必要があると考えている.

\section{4 さらに行き届いた被災情報の活用を目指して}

本システムはインターネット経由で得られる情報を収集・分析し, ユーザからの質問に備え る.図 6 は，本システムを災害時にどのように運用するかを示したイメージ図である。各種救 援団体，例えば，炊き出しを行うボランティア団体などは，自らの炊き出し実施場所を決める ためにどこで炊き出しを行っているかをシステムに質問し，そのすべての回答を地図上に表示 することで，炊き出しが行われていないエリアを確認できる，一方，被災者など個人レベルで 本システムを利用する場合には, 自分の周辺の状況を把握し, 意思決定の助けとするような使 い方や，また把握した状況に基づき，自らの周辺状況や救援要請を発信するなどの使い方を考 えている。このように，本システムは災害時において，ソーシャルメデイア等に溢れる情報を 整理し, 救援団体や, 自治体, 被災者らに対して被災状況の全体的把握を容易にする情報をわ かりやすく提示することで，被災者の救援・支援に有効である. 


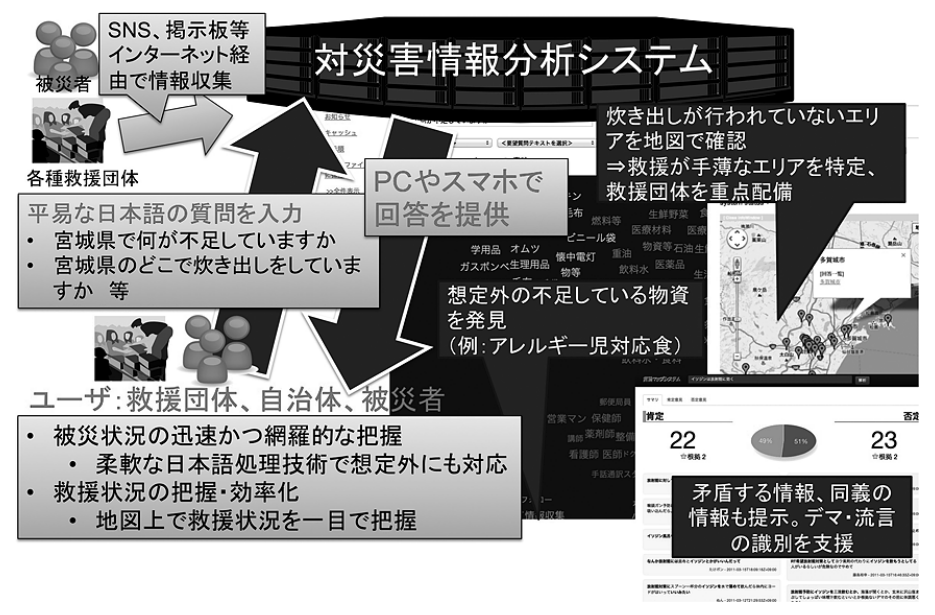

図 6 災害時における提案システム運用イメージ

一方で，災害時においては，通信状況等様々な制約から，回答のすべてを確認することが困難 な状況も考えられる。そこで，重要と考えられる回答の一部を表示するために，結果をランキ ングできることが望ましいが，質問に対する一般的な回答の適切さのみならず，過去 5 分以内 に挙げられた情報を求める場合のように情報の新鮮さを重視する場合や，回答の利用目的（見 落としているかもしれないものにはやく気づきたい）などによっていくつかの基準が考えられ る，時刻による限定は，現在機能として有しているが，ランキングの基準とあわせて今後利用 者にとってさらに使いやすくすべきである．

さらに，インターネット経由でつぎつぎに情報（テキスト）が流れ込んでくる状況において は, システムが大規模コーパスから獲得して利用している知識, 例えば, 意味クラス辞書や, 含 意パターンデータベースを拡張可能かもしれない。しかしながら，これらのデータベースは， 一度，大規模なコーパスから獲得してしまえば，大部分のものは長く使えるものである。特に 含意パターンデータベースは, 名詞句が変数となっており, その経時的変化は非常にゆるやか であると考える。災害発生後にそれまで使っていたパターンとは全く異なるパターンで情報発 信することは考えにくい. したがって，事前に大規模なコーパスから獲得した知識を用いてい ることによって損なわれる有用性は非常に限定されると考える。もちろん，オンライン学習等 によって常時知識が更新されつづけるようシステムに拡張すべきであることは言うまでもない.

本論文の冒頭で示唆したように，今回の震災時には被災者からの tweet が必ずしも救援者へ 届いていないという問題があったようである，本システムは，被災地からの情報を全体的俯瞰 的に把握することを可能とする。しかしながら, 一度質問した内容でも, 対応する情報は被災 地の各地から質問後も不定期に投稿される可能性が高く，その情報は常に更新される．比較的 落ち着いた時期になれば，定期的に分析システムを利用すればよいが，災害時に様々な対応が 
必要な自治体などの支援者側は思うようには反応することができないことが予想される．また， 情報発信を行っている被災者サイドでも発信した情報が適切な救援者に届いているか否かが不 明な状況では，例えばさらに遠くへ避難するか，それとも救助を待つかといった切迫した判断 を行えないといった問題が生じえる.

そこで，我々は，図 7 に示すように，本システムの回答インデックス作成モジュールを拡張 し，予救援者がシステムに登録した質問に対しては，以後の tweet や指定したBBS，揭示板 に情報が発信された場合に，システムがその内容が登録済みの質問の回答となるかをリアル夕 イムで判断し，救援者サイドの情報のアップデートを行うとともに，情報提供者にも，質問を 登録した救援者にその情報が届いたことが通知される枠組みを開発している。この処理により， 図 8 のように，情報提供者，被災者は自らの発信した情報か救援者に届いたことがわかりその後 の意思決定が容易になるとともに，救援者側は欲している情報をリアルタイムで定常的に取得

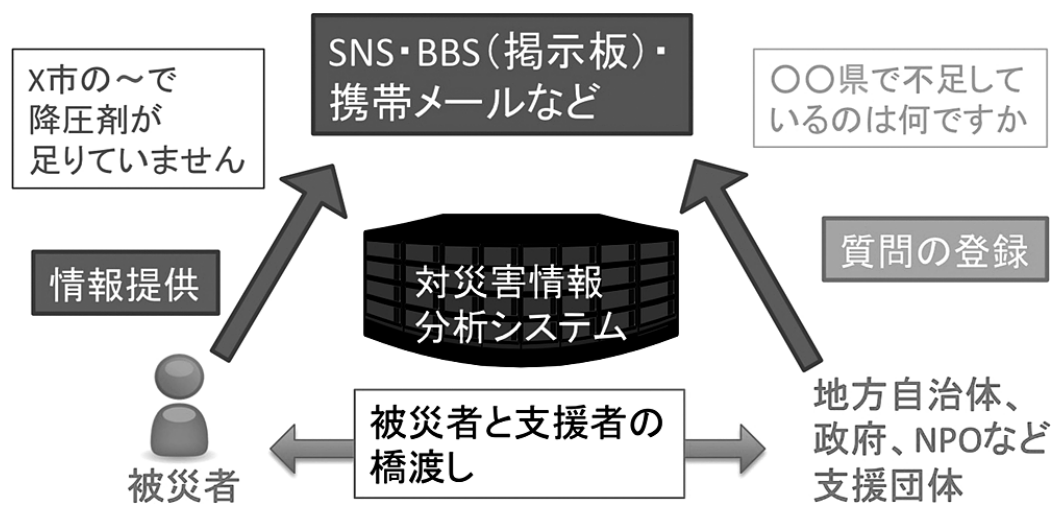

図 7 被災者と救援者の双方向のコミュニケーション

\section{NICT 対災害情報分析揭示板 プロトタイプ}

\section{揭示板に戻る 全部 最新 50}

宮城県で不足しているもの

12 : demo_user 2013/04/02(火) 17:48:27

石巻市で防寒着が不足しています。

\section{3 : 対災害質問応答システムボット 2013/04/02(火) 17:48:27}

$\gg 12$

NictNpoさん の質問「石巻市では何が不足していますか」の回答として認識されました。 NictNpoさん のPCで表示されているものと思われます。

図 8 掲示板上での動作例 
することができ，支援のスピードアップにつながると考えられる。こうした一連の操作は，一 言で言えば, 現状のマイクロブログ, SNS，掲示板等のいわば一方通行の情報提供から，被災者 サイドと支援団体等救援者サイドの双方向のコミュニケーションを担保することとも言え，こ うした操作によってよりスピーディかつ適切な救援, 避難等が実現できるのではないかと考え ている。

こうした処理は，これまでに説明した質問応答の処理の方向を大幅に変更することなく実現 できる。通常の質問応答処理では，パターントリプルもしくは部分パターンの形式でインデッ クスに登録された tweet からの情報を，質問から取得したパターントリプル等を含むクエリに より検索するが，ここでは，あらかじめ登録された質問に対して，含意パターンなどの獲得を 事前にやっておき，含意パターンも含むようなパターントリプル等をキー，質問を值とする別 種のいわば質問のインデックスを作成しておく.

例えば，「宮城県で不足しているのは何ですか？」といった質問が登録されているとするなら

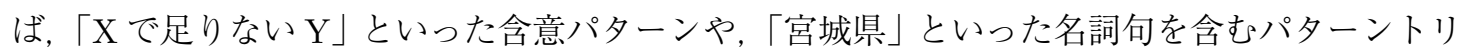
プルをキーとし，「宮城県で不足しているのは何ですか」という質問を值とするような質問のイ ンデックスが作成される。掲示板等の記事や tweet が新規にシステムに渡されると, 将来問わ れる質問にそなえてこれまでに説明してきた回答インデックスが作成されるが，その際，生成 されるパターントリプルをキーとして，過去に登録された質問のインデックスを検索する。も しこの質問のインデックスの検索がヒットすれば, 值となっている登録済み質問の回答をアッ プデートするとともに, 対応する新規の tweet, 記事等の作者に対して, 登録された質問への回 答として提供された情報が認識されたことを通知する。現状は，こうした枠組みをサーバー一 台の上で動作させることができており，今後，大規模な計算機クラス夕上等で想定されるよう な大量の情報がやってきたときでもリアルタイムの処理が可能なシステムを開発していく予定 である。

本システムのもう一つの応用としては, ソーシャルメディア上で流通している様々なデマの 早期発見とエキスパートによる反論を支援するものが考えられる。例えば，図 9 で「放射能に 効くのは何ですか」という質問に対してのシステム出力を示す,「イソジン」,「わかめ」,「活性 炭」など，デマと思われるものが大量に含まれる。このような質問も予めにシステムに登録す ることで，信頼性が低い情報あるいは有害情報が懪発的に拡散される前に，書き达まれた時点 に認識され，デマが大量に拡散する以前にエキスパートによってデマを打ち消す情報をスピー ディに発信することが可能となると考えられる.

また，本システムが提示する回答にはそもそも大量のデマが含まれている可能性があるが, 我々は本システムを東北大学で開発されている言論マップ (水野, Nicoles, 渡邊, 村上, 松吉, 大 木, 乾, 松本 2011) と組み合わせることで回答を閲覧したユーザが回答のデマ性についてより適 切な判断を下すことができるようになると考えており，実際に言論マップとの統合を計画して 


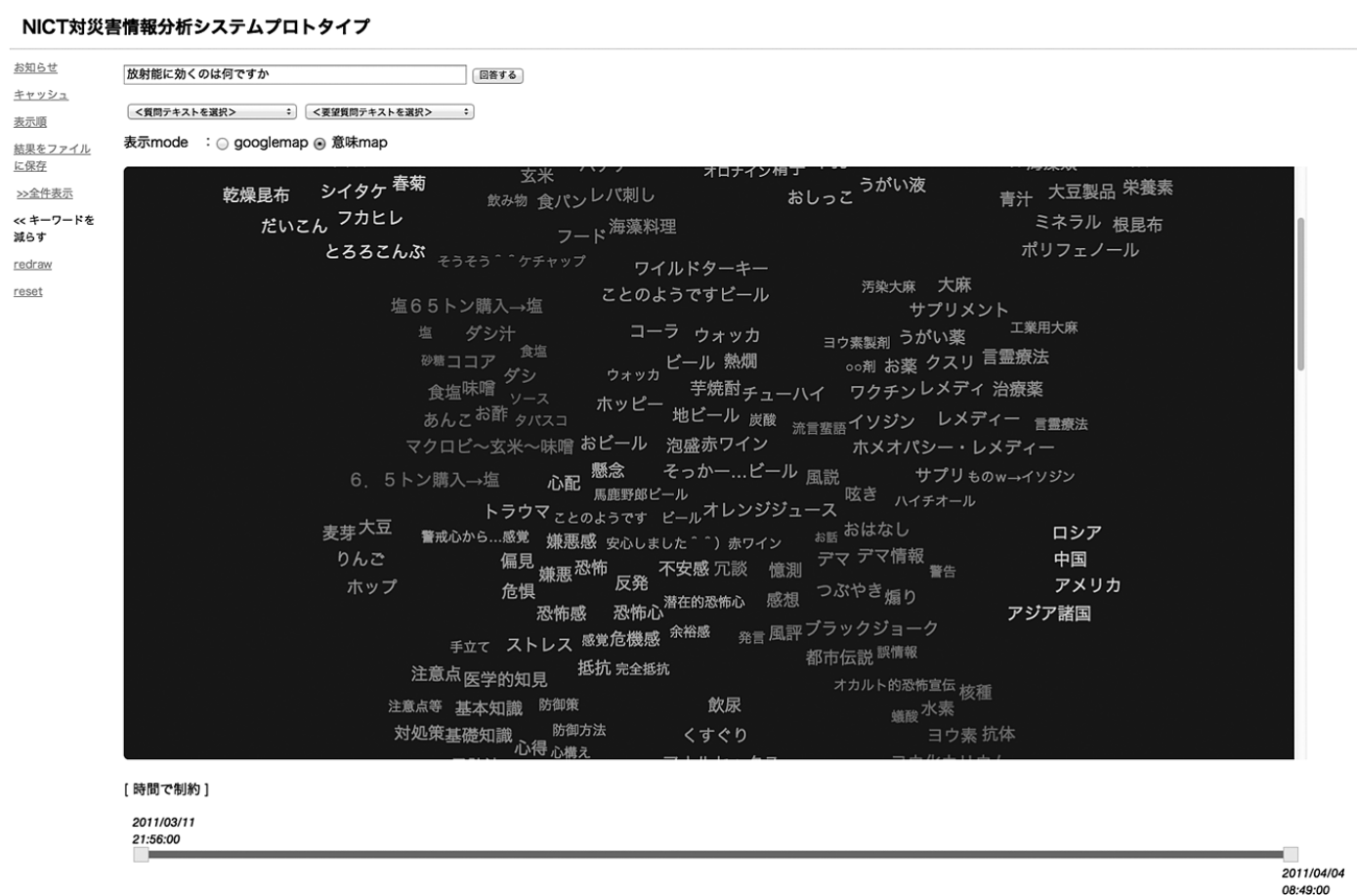

図 9 「放射能に効くのは何ですか」という質問に対するシステム出力

いる，現在の言論マップでは，例えば「イソジンは放射能に効く」という情報に対して，それ を肯定している情報と否定している情報をソーシャルメディア上の情報から発見して提示する ことが可能である。こうした肯定的情報，否定的情報は通常のソーシャルメディアの閲覧環境 では簡単に見つけることは難しいが，本システムに言論マップを組み合わせることで，回答に は常に肯定的情報，否定的情報をあわせて表示することが可能となり，ユーザは疑わしい情報 に関しては，こうした情報を参考にしつつその真偽を判断する材料とすることができる.

\section{5 関連研究}

近年では，検索エンジンや質問応答システムなど，情報へのアクセス手段の進歩が目覚まし い. 例えば，質問応答システムとしては IBM 社の Watson (Ferrucci, Brown, Chu-Carroll, Fan, Gondek, Kalyanpur, Lally, Murdock, Nyberg, Prager, Schlaefer, and Welty 2010) がクイズ番組 の人間のチャンピオンに圧勝し一躍有名になった. Watson は, Wikipedia を含む辞書, 辞典や 台本など Jeopardy というクイズ番組の分野に関連する確かな知識を予め選別し, データベース 化している，少なくとも我々の知る限り，情報のリアルタイム更新については想定していない 
ため，逐次更新される災害時の情報などには対応していない，また，災害時に必要なのは，多 数の情報を俯瞰的に閲覧することであるが，すくなくともJeopadyにおいて質問はその回答が 一意に定まるものに限られており，Watson が現状すぐに災害時の情報などに適用できるかどう かは不明確である。

また，日本においても，「しゃべってコンシェル」(吉村 2012) と呼ばれる携帯電話のサービ スが注目を浴びている。このシステムは，携帯電話を用いて質問応答を行うものであり，Web の更新データに対応している。このサービスでの質問応答では，「ハリーポッターの監督は誰」 のようなある対象物（ハリーポッター）の属性（監督）を聞くタイプの質問は，回答が一意に 定まる知識について Watson と同じように予め知識のデータベース化を行っている，また，天 気やニュースなどについては専用のサービスの結果を返し，それ以外の質問は，キーワード検 索と固有表現による質問応答手法を利用している。それでも見つからない場合はキーワードに よる検索結果を出力する.

我々のシステムは, 上記のシステムとは異なり, これまでの含意獲得の研究をもとに, 質問文 からの含意パターンや部分パターンを取り出し，そのパターンを元に回答を求めている。その ため，質問文から何らかのパターンが獲得できれば，高い精度で回答が可能である，また，固 有表現でない一般名詞が回答の場合や，これまでの固有表現 (Sekine and Isahara 2000; Sekine 2008) では対象としていない表現についても，回答を出力できる．固有表現は，特定の質問に対 しては重要な要素であることは間違いないため, 今後, 回答のランキングに固有表現に関する 素性を取り入れて行く予定である。また，災害時の質問にも，一意に定まる質問がされる可能 性はあるため, Wikipedia などの知識を利用した手法 (Buscaldi and Rosso 2006) もシステムも 取り入れて行く.

\section{6 おわりに}

本論文では, 想定外のものもふくめて, 災害時の情報を俯瞰的に把握するために開発した, 質 問応答に基づく情報分析システムについて述べ，また，東日本大震災時の tweet データを利用 した性能評価について報告した，さらに，本システムを拡張することによって，比較的実現容 易な形で, リアルタイムで被災者と救援者が双方向のコミュニケーションを行うことを可能と し，より効率的な救援活動やより適切な避難行動等を支援する枠組みについても提案した。ま た，東北大学で開発されている言論マップ技術との統合や，リアルタイムでの回答の更新によっ て，東日本大震災時に問題となったデマに対処する枠組みも提案した.

様々な質問に対して回答を提示できるようにするために，本システムでは，質問応答処理に おいて構文パターンの言い換えに基づく質問文の拡張を行い, さらに場所や地名の補完処理を 加えることで，幅広い質問に対応した。また，得られた回答を意味クラスごとにまとめるイン 
ターフェースと回答を地図上に表示するインターフェースを用意することで被災地の状況や救 援状況の俯瞰的把握を可能とした，人手で作成した質問を基にした評価実験では，複合語処理 の問題や要望, 疑問, 仮定を含む tweetの特定の必要性が明らかになった。必要な情報を必要 な人に行き渡らせるためには，たとえその回答を必要としている人が一人であっても，回答を 提示することが望ましい，こうした点に鑑み，ロングテール部分に存在する被災者の要望にも 応えることができる情報分析システムの構築を今後も進めていく予定である.

より具体的には, 現在 5 万件以上からなる災害に関連の深い含意パターンの学習デー夕を人 手で構築しつつあり, さらに, その他の言語資源も構築中である. 今後, こうしたリソースを 活用しつつ，また，新規のアルゴリズムを導入することによって性能向上を図っていく予定で ある。

\section{謝 辞}

本研究で利用しているデータは, 株式会社ホットリンク様よりご提供頂きました。ここに記 して感謝致します.

\section{参考文献}

Bloom, B. (1970). "Space/time Trade-offs in Hash Coding with Allowable Errors." Communications of the ACM, 13 (7), pp. 422-426.

Buscaldi, D. and Rosso, P. (2006). "Mining Knowledge from Wikipedia for the Question Answering Task." In Proceedings of the International Conference on Language Resources and Evaluation (LREC), pp. 727-730.

Cheng, Z., Caverlee, J., and Lee, K. (2010). "You Are Where You Tweet: A Content-Based Approach to Geo-locating Twitter Users." In Proceedings of the 19th ACM International Conference on Information and Knowledge Management (CIKM), pp. 759-768.

De Saeger, S., Torisawa, K., Kazama, J., Kuroda, K., and Murata, M. (2009). "Large Scale Relation Acquisition using Class Dependent Patterns." In Proceedings of the IEEE International Conference on Data Mining (ICDM), pp. 764-769.

Ferrucci, D., Brown, E., Chu-Carroll, J., Fan, J., Gondek, D., Kalyanpur, A. A., Lally, A., Murdock, J. W., Nyberg, E., Prager, J., Schlaefer, N., and Welty, C. (2010). "Building Watson: An Overview of the DeepQA Project." AI Magazine, 31 (3), pp. 59-79.

Fleiss, J. (1971). "Measuring Nominal Scale Agreement among Many Raters." Psychological Bulletin, 76 (5), pp. 378-382. 
Harris, Z. (1954). "Distributional Structure." Word, 10 (23), pp. 142-146.

Hashimoto, C., Torisawa, K., De Saeger, S., Oh, J., and Kazama, J. (2012). "Excitatory or Inhibitory: A New Semantic Orientation Extracts Contradiction and Causality from the Web." In Proceedings of the 2012 Joint Conference on Empirical Methods in Natural Language Processing and Computational Natural Language Learning (EMNLP-CoNLL), pp. 619-630.

川田拓也, 大竹清敬, 後藤淳, 鳥澤健太郎 (2013). 災害対応質問応答システム構築に向けた質 問・回答コーパスの構築. 言語処理学会第 19 回年次大会発表論文集, pp. 480-483.

風間淳一, De Saeger, S., 鳥澤健太郎, 後藤淳, Varga, I. (2012). 災害時情報への質問応答シス テムの適用の試み.言語処理学会第 18 回年次大会講演論文集, pp. 903-906.

Kazama, J. and Torisawa, K. (2008). "Inducing Gazetteers for Named Entity Recognition by Large-Scale Clustering of Dependency Relations." In Proceedings of the 46th Annual Meeting of the Association for Computational Linguistics: Human Language Technologies (ACL-08: HLT), pp. 407-415.

Kloetzer, J., De Saeger, S., Torisawa, K., Sano, M., Goto, J., Hashimoto, C., and Oh, J. (2012). “Supervised Recognition of Entailment between Patterns." 言語処理学会第 18 回年次大会 講演論文集, pp. 431-434.

Liu, X., Wei, F., Zhang, S., and Zhou, M. (2013). "Named Entity Recognition for Tweets." ACM Transactions on Intelligent Systems and Technology, 4 (1), pp. 1-15.

水野淳太, Nicoles, E., 渡邊陽太郎, 村上浩司, 松吉俊, 大木環美, 乾健太郎, 松本裕治 (2011). 言論マップ生成技術の現状と課題. 言語処理学会第 17 回年次大会講演論文集, pp. 49-52.

Neubig, G., Matsubayashi, Y., Hagiwara, M., and Murakami, K. (2011). "Safety Information Mining-What Can NLP Do in a Disaster-." In Proceedings of the 5th International Joint Conference on Natural Language Processing (IJCNLP), pp. 965-973.

Ritter, A., Clark, S., Mausam, and Etzioni, O. (2011). "Named Entity Recognition in Tweets: An Experimental Study." In Proceedings of the 2011 Conference on Empirical Methods in Natural Language Processing (EMNLP), pp. 1524-1534.

Sekine, S. (2008). "Extended Named Entity Ontology with Attribute Information." In Proceedings of the International Conference on Language Resources and Evaluation (LREC).

Sekine, S. and Isahara, H. (2000). "IREX: IR and IE Evaluation Project in Japanese." In Proceedings of the International Conference on Language Resources and Evaluation (LREC), pp. $1475-1480$.

Yamada, I., Torisawa, K., Kazama, J., Kuroda, K., Murata, M., De Saeger, S., Bond, F., and Sumida, A. (2009). "Hypernym Discovery Based on Distributional Similarity and Hierarchical Structures." In Proceedings of the 2009 Conference on Empirical Methods in Natural 
Language Processing (EMNLP), pp. 1172-1181.

吉村健 (2012). しゃべってコンシェルと言語処理. IPSJ SIG Technical Report Vol. 2012-SLP-93

(4), pp. 1-6.

\section{略歴}

後藤＼cjkstart淳：1993 年徳島大学大学院工学研究科修士課程修了. 同年日本放送協 会入局. 2011 年より独立行政法人情報通信研究機構専門研究員. 現在, 総合 研究大学院大学博士課程在学.

大竹 清敬： 2001 年豊橋技術科学大学大学院博士後期課程修了. 博士 (工学). 同年より株式会社 ATR 音声言語コミュニケーション研究所. 2006 年より独 立行政法人情報通信研究機構. 音声言語処理, 自然言語処理の研究に従事.

Stijn De Saeger: 2006 年北陸先端科学技術大学院大学博士課程修了. 博士（知 識科学). 独立行政法人情報通信研究機構専攻研究員を経て, 現在同機構主任 研究員. 知識の自動獲得の研究に従事. 言語処理学会第 16 回年次大会優秀発 表賞等受賞.

橋本 力： 2005 年京都大学研究員, 2007 年山形大学助教, 2009 年独立行政 法人情報通信研究機構専攻研究員. 現在, 同機構主任研究員. 博士（言語科 学, 情報学)，情報処理学会論文賞, 言語処理学会論文賞, 同学会優秀発表賞 等受賞.

Julien Kloetzer: 2006 年パリ第 6 大学卒業, 2010 年北陸先端科学技術大学院 大学博士課程修了. 博士 (情報科学)。2011 年独立行政法人情報通信研究機 構入所. 現在, 同機構情報分析研究室研究員.

川田 拓也：2003 年国際基督教大学教養学部卒業. 2010 年京都大学大学院文学 研究科博士後期課程修了. 博士 (文学). 現在, 独立行政法人情報通信研究機 構情報分析研究室研究員. 言語資源の設計と構築に従事.

鳥澤健太郎：1995 年東京大学大学院理学系研究科中退. 同年同専攻助手. 北陸 先端科学技術大学院大学助教授を経て, 現在, 独立行政法人情報通信研究機 構・情報分析研究室室長及び情報配信基盤研究室室長. 博士（理学）．日本学 術振興会賞など受賞. 